IZA DP No. 4216

The Nature and Extent of Job Separations in Germany: Some New Evidence from SOEP

Getinet Haile

June 2009 


\title{
The Nature and Extent of Job Separations in Germany: Some New Evidence from SOEP
}

\author{
Getinet Haile \\ Policy Studies Institute, \\ University of Mannheim and IZA
}

\author{
Discussion Paper No. 4216 \\ June 2009
}

IZA
P.O. Box 7240
53072 Bonn
Germany

\author{
Phone: +49-228-3894-0 \\ Fax: +49-228-3894-180 \\ E-mail: iza@iza.org
}

\begin{abstract}
Any opinions expressed here are those of the author(s) and not those of IZA. Research published in this series may include views on policy, but the institute itself takes no institutional policy positions.

The Institute for the Study of Labor (IZA) in Bonn is a local and virtual international research center and a place of communication between science, politics and business. IZA is an independent nonprofit organization supported by Deutsche Post Foundation. The center is associated with the University of Bonn and offers a stimulating research environment through its international network, workshops and conferences, data service, project support, research visits and doctoral program. IZA engages in (i) original and internationally competitive research in all fields of labor economics, (ii) development of policy concepts, and (iii) dissemination of research results and concepts to the interested public.
\end{abstract}

IZA Discussion Papers often represent preliminary work and are circulated to encourage discussion. Citation of such a paper should account for its provisional character. A revised version may be available directly from the author. 
IZA Discussion Paper No. 4216

June 2009

\section{ABSTRACT \\ The Nature and Extent of Job Separations in Germany: Some New Evidence from SOEP}

This paper analyses job separations in Germany using data from the German SocioEconomic Panel spanning from 1984 to 2003. Based on detailed reasons for job separation and different SOEP samples, the paper attempts to establish the nature of job separations in Germany. It brings to light some patterns of separations that have hitherto been unexplored. The findings of the study suggest, among others, that minority group status is important in characterising job separations, particularly in the event of exogenous shocks. Targeting minorities in the face of a major shock of the sort experienced in Germany might be a policy option.

JEL Classification: J6, J15, C35

Keywords: job separations, job turnover, economics of minorities

Corresponding author:

Getinet A. Haile

Policy Studies Institute

50 Hanson Street

London W1W 6UP

United Kingdom

E-mail: g.haile@psi.org.uk 


\section{Introduction}

Job separations represent the dissolution of employer-employee job matches and they may take different forms. In general, although job separations form part of the normal operation of a labour market, they may have adverse consequences. This may be particularly the case for employees who separate from their job involuntarily. Involuntary job separation that is followed by a period of unemployment, for example, may result in loss of human capital or it may curtail the prospect of reemployment due to adverse signalling. Voluntary separations, on the other hand, may entail costs of recruitment and training for firms. In the event of non-random separations, studying the nature and extent of job separations is essential as this helps shed some light on the nature and extent of job separations thereby informing possible interventions. This paper attempts to attain this goal by investigating job separations in Germany.

Determining the nature and extent of job separations will serve at least four important purposes. First and foremost, it will enable us to identify who separated workers are and which types of jobs/sectors they separate from. Secondly, it will allow us to gain some insight into the degree of flexibility of the labour market in question. Third, it has long been established that good information on job separation and turnover is a key building block for formulating theories of unemployment and labour market dynamics. Fourth and most importantly, good information on the type and nature of job separation will inform interventions aimed at minimising the adverse effects of separations.

There has been very little work studying job separations and turnover in Germany and the few existing studies do not bring out some aspects of separations, such as those pertaining to minorities, which this study attempts to bring to light by studying the different samples of SOEP separately. The remaining part of the paper is organised as follows. Section 2 makes a review of the literature on job separations and turnover. Section 3 focuses on the data and sample used in the empirical analysis carried out. Section 4 gives a brief account of the econometric methodology and estimation strategy employed. Section 5 discusses the empirical results and the final section concludes the paper.

\section{The literature on job separations}

The job separations literature relates to theories of turnover that identify three different types of separations. First, there are separations that are initiated by a worker. Such separations are the result of the labour supply decisions of the worker and represent quits or voluntary separations. Second, there are separations initiated by a firm. Such separations are largely the result of labour demand conditions and form layoffs or involuntary separations. Finally there are separations that are the result of a joint decision by the worker and the firm (Anderson P and Meyer B, 1994). A number of theoretical explanations have been put forward by way of explaining these separations. Human capital theory (Mincer 1958, 1962; Schultz 1960, 1961; Becker 1962, 1964; Ben-Porath 1976; Parsons 1972; Willis 1986; Weiss 1995) emphasise the importance of human capital or sharing of the investment in human capital between the firm and the worker in formalising job separations in general and the tenure- 
earnings profile in particular. Imperfect information based explanations of turnover (Spence 1973; Salop and Salop 1976); on the other hand, emphasise the importance of informational asymmetry in characterising turnover and separations. Later formalisations of the imperfect information explanation emphasised the importance of match capital and the notion of efficient turnover in explaining separations (McCall 1970; Mortensen 1977, 1986; Burdettt 1978; McLaughlin 1991; Devine and Kiefer 1991; Mortensen and Pissarides 1999).

The theoretical formalisations and empirical studies have led to some commonly identified stylised facts regarding job separations and separators, though most of these relate to the US labour market. In terms of worker characteristics, previous studies on the US find, among others, less skilled workers, those in 'declining sectors' and those with short tenure to be more likely to experience layoff. In terms of gender, the evidence suggests that men are more likely to experience layoff while women are more likely to quit (Hall 1972, Blau and Kahn 1981, Hammermesh 1989, Farber 1993, 1997, Fallick 1996, Kletzer 1998). More recent evidence suggests workers that experience layoff appearing more like the general workforce, particularly since the 1980s. Farber (1993, 1997), for example, finds some evidence where workers with longer experience and more education becoming more at risk of experiencing layoffs in recent decades than had been the case previously.

Efficient turnover models have strong and consistent finding that there is a negative relationship between quits and layoffs, on the one hand, and job tenure, on the other (Jovanovic 1979a; 1979b; 1984) and attribute this to match and firm-specific human capital that accumulate with tenure. Blau and Kahn (1981) argue that a negative coefficient for tenure on the job may reflect the fact that workers with longer tenure have little experience of layoffs or quits before. In such a case, the tenure on the job variable may reflect individual fixed effects where those individuals with longer tenure are less prone to separations in general.

The evidence on job separations in European labour markets is rather limited and this has been linked to low level of turnover and inflexibility in most European labour markets. Winkelmann and Zimmermann (1998), Heckman (2002), for example, note inflexibility of European labour markets as a factor explaining the high level of unemployment problem. Although limited, the evidence on the characteristics of separators thus far is in line with findings for the US labour market. In their study of the German labour market, Burda and Mertens (2001), find that layoff is concentrated among lower wage earners, highlighting the importance of job characteristics in explaining involuntary separations. Hazard rate based evidence of transition from work (Bergemann \& Mertens 2004), show that German men face a higher risk of experiencing layoffs while women face a higher risk of quit.

\section{The data and sample}

The data used in this paper come from the German Socio-Economic Panel (SOEP) data, a panel survey of representative households in Germany, spanning over the period 1984 to 2003. The SOEP started in 1984 monitoring some 5921 households and 12290 individuals in West Germany. The SOEP has not only been surveying the original households and their split-offs, thereby becoming one of the longest running panel studies in the world, but it has also been incorporating new sub-samples in an 
attempt to have an ever more representative sample of the German society. The SOEP is also reported to be one of the most stable surveys with 63 per cent of the original households and 55 per cent of the respondents in them still being interviewed two decades later in $2004^{1}$.

One of the core issues the SOEP has been monitoring is changes in employment and occupational status of respondents. In particular, respondents are asked, in each wave, whether they experienced a change in their employment situation since the previous interview and, if so, the reasons for the change. As can be seen from Table A1 in the appendix and the notes therein, the reasons for job separation monitored are extensive and rich, providing ample opportunity for studying the nature of job separations. In this study the extensive set of reasons monitored is re-classified into three categories, viz., 'Layoff', 'Quit' and 'Other' types of separations. By comparing separators and their counterparts with no experience of job change ('Stayers') in each year covered by the study, it is possible to establish the nature of job separations in Germany².

Two of the original SOEP samples, samples A and B, have been used in this study. Sample A is a sample of native (west) Germans who have been monitored since 1984. Sample B, on the other hand, is a sample of households with foreign-born heads, also called the 'guest-worker' sample, that make up the second of the original two samples that started in 1984. Considering the apparent differences in the nature of these samples, the empirical analysis undertaken in this study is carried out separately for the two samples. Also, separate analysis is done for men and women in each case, taking into account the difference in the labour market behaviour of men and women.

Individuals included in the final sample are working age individuals (16-65 years of age) that were interviewed successfully in each wave they were monitored. Individuals with gap(s) in yearly observations have been excluded from the estimation sample for gaps would create ambiguity as to whether there was a job separation and the reason(s), if any, for the same. Individuals in the study sample should also have weekly working hours of between 5 and 80 hours, inclusive, and have non-missing monthly earnings. ${ }^{3}$ As well as these sample selection restrictions, individuals should have non-missing job tenure to be included in the study sample and, for those workers that experienced a job change, there has to be a valid information for the 'reasons for job change' variable. The resulting sample obtained and their characteristics are summarised in Tables A3-A4 in the appendix.

As can be seen from Tables A3-A4, younger workers are more likely to separate due to 'layoff' and 'quit' in both samples and both for men and women. On the other hand, 'other' movers are more likely to be either young or old which is not surprising given the reasons making up the 'other' category that include 'conscription', 'completion of training' and 'early retirement', among others. 'Stayers' come dominantly from the middle sections of the age bracket and are generally more likely to be married, have children under 16 years of age and own a house than separators. Irrespective of sample or gender type, those with disability ${ }^{4}$ are more likely to make up the 'layoff' and 'other' reason categories. There are also some noticeable differences between the two samples. For example, the proportion of workers owning a house is higher for natives than guest-workers. 
In terms of job related characteristics, most native men and women are in jobs that require some kind of training course while guest-worker men and women are more likely to be in jobs that do not require training or that require only introduction to the job. This is also reflected in their respective occupations, where the former largely make up the professional/managerial and skilled occupations while the latter tend to be in the unskilled or semi-skilled occupational categories. There is also some gender dimension to the observed occupational profiles of the final sample in that women from the guest-worker sample are more likely to be in unskilled occupations compared with their native counterparts who are more likely to be in professional/managerial occupations. 'Stayer' guest-worker women are the only exception in that they are more likely to be in semi-skilled occupations.

In both samples and for both sexes, movers dominantly come from smaller firms visà-vis 'stayers' who tend to be employed in large firms. In terms of industry of employment, manufacturing is the most common sector of employment for men in both samples and women from the guest-workers sample. On the other hand, trade and social services industries are the most common sectors of employment for native women, particularly for 'stayers'. In both samples and for both men and women, 'quits' are associated with short job tenure while 'stayers' are observed to have the longest tenure on the job.

Figures A1-A4 in the appendix plot the percentage of people in the final sample experienced the three separations identified ('layoffs', 'quits' and 'other'). ${ }^{5}$ There are very little differences in the patterns of observed separations between men and women within each sample. There are however major differences in these patterns between the samples. For example, the average rates of 'layoffs', 'quits' and 'other' separations over the study period stand, respectively, at 2.5, 6.7 and 3.9 percentage points for native men. The corresponding rates for guest-worker men stand at 4.3, 5.9 and 2.9 percentage points.

Comparing the rates of separations for the per- and post-reunification periods indicates that in the post period the rates of 'layoffs' and 'other' separations have gone up by up to 66 percentage points while 'quits' have fallen by up to 48 percentage points. These patterns are consistent with predictions of theories of turnover regarding the cyclicality of 'quits' and 'layoffs' and reflect, barring recall and misclassification errors, the tougher labour market situations that accompanied re-unification. ${ }^{6}$ The cyclical patterns of 'layoffs' and 'quits' shown in Figures A1-A4 as well as the higher proportions of 'quits' for women conform to predictions of theories of turnover. ${ }^{7}$ That 'layoffs' have gone up proportionately more for guest-workers in the immediate postre-unification period seems to reveal that the price of re-unification might have been higher for this group.

\section{A framework of analysis}

As stated in the previous section, three categories of workers have been identified depending on the type of job separations they experienced in each year they were observed. Identifying, in each year, workers that do not experience job separation renders a fourth category of 'stayer' workers. The empirical approach appropriate in situations involving unordered multiple alternatives of this sort is the multinomial probability model. In this study, use is made of the multinomial logit model to model 
the four distinct categories identified and to establish the nature of job separations in Germany. It is essential to test whether the four categories identified can be collapsed before proceeding into the formal modelling. ${ }^{8}$ As can be seen from Table A2 in the appendix, the tests whether these categories can be collapsed have been rejected, lending support to the empirical approach employed. ${ }^{9}$

Thus, assuming that $j$ indexes the $J$ possible categories of workers at time $t$ and letting $X_{i t}$ denote the vector of characteristics specific to an individual occupying a particular category at time $t$, the probability that the individual with characteristics $X_{i t}$ occupies category $J=j$ can be given by,

$$
\operatorname{Prob}\left(j \mid X_{i t}\right)=\frac{\exp \left(X_{i t} \beta_{j}\right)}{\sum_{k=1}^{J} \exp \left(X_{i t} \beta_{k}\right)}, \quad j=0,1, \ldots, J
$$

It goes without saying that unobserved factors, such as unobserved ability and motivation, are likely to play a role in determining whether a worker experiences a particular type of job separation or not. For example, high ability workers may be less likely to experience a 'layoff' or they may be able to establish a good match early on in their career and be 'stayers' with stable jobs. Taking into account the importance of unobserved factors in explaining job separations, the modelling approach employed in this study exclusively accounts for unobserved heterogeneity. The mixed multinomial logit (MMNL) model that accounts for unobserved heterogeneity is obtained by augmenting equation (1) so that;

$$
\operatorname{Prob}\left(j \mid X_{i t}, v_{i}\right)=\frac{\exp \left(X_{i t} \beta_{j}+v_{i j}\right)}{\sum_{k=1}^{J} \exp \left(X_{i t} \beta_{k}+v_{i k}\right)}, \quad j=0,1, \ldots, J
$$

An empirical issue of importance is to do with the distribution of the unobserved heterogeneity term $v_{i}$. In the absence of any theoretical justification, imposing a particular shape on the unobserved heterogeneity term may be misleading. In this study unobserved heterogeneity is modelled as a finite discrete distribution of masses of unrestricted form following the approach in Heckman and Singer (1984). Unobserved heterogeneity is modelled non-parametrically using discrete mass points for the heterogeneity term $v_{i}$ and its density function $g_{v}(v)$, The number and location

of the mass points, $\hat{\theta}_{1}, \ldots, \hat{\theta}_{m}$, and associated probabilities, $\hat{\pi}_{1}, \ldots, \hat{\pi}_{m}$, are estimated together with other parameters of interest. ${ }^{10}$

\section{Empirical results and discussion}

The regression results from the MMNL models estimated separately for men and women in each sample are reported in Tables 1 and 2. ${ }^{11}$ As the discussion in the following paragraphs shows, the empirical findings in this study are consistent with predictions of theories of turnover and previous studies of similar nature reviewed in section 2. The findings also reinforce the assertions made in Section 3 based on the summary statistics provided. The following paragraphs provide a detailed account of these findings. 


\subsection{Demographic and human capital characteristics}

In terms of demographic characteristics, the estimated coefficients suggest that workers under 35 years of age are generally significantly more likely to experience job separation primarily due to 'other' reasons but also as a result of 'quit' vis-à-vis a reference group of workers aged 35 to 44 years. On the other hand, workers over 45 years of age are significantly less likely to separate due to 'quit' while those over 55 years of age are generally more likely to separate because of 'layoff' and 'other' reasons'. There are some noticeable differences in the patterns of separations between the two samples and between men and women. For example, no significant effect of separation due to 'layoff' is found for women of any age category in the two samples and men in the guest-worker sample. The dummy for whether one is over 58 years old, which is meant to capture possible effects of early retirement schemes on job separations, indicates that such workers are significantly more likely to separate due to 'other' and 'quit' reasons and unlikely to separate due to 'layoffs' as would be expected.

Excepting for guest-worker women for whom no significant effect of owning a house is found, workers that own a house are found to be significantly less likely to separate from their job, particularly for men and women in the native sample. One significant effect that traverses the sample and gender boundary has to do with disability. Accordingly, workers with some form of disability are significantly more likely to experience job separations due to 'layoff', 'quit' and 'other' reasons and less likely to stay.

\section{$5.2 \quad$ Job and employment characteristics}

Job related characteristics in general and firm size, industry of employment, job tenure and wage level, in particular, shed more light into the nature of job separations in Germany. Looking at the type of training required for the job, we find that with the exception of native men in jobs that required college level training, who are significantly less likely to separate from their job due to 'quit', other workers in jobs that required college level training are more likely to separate due to 'layoff' and 'quit' compared with their counterparts who are in jobs that only required taking short courses.

With regards to firm size, workers in firms with less than 200 employees in general and those with less than 20 workers in particular are generally more likely to separate due to 'layoff' and 'quit' vis-à-vis workers employed in firms with 200 to 2000 workers. In terms of industry of employment, all but guest-worker men in the manufacturing; wholesale trade, hotel and restaurant; mining and construction; and agriculture, transport, finance and real estate industries are significantly more likely to separate from their job due to layoff and generally significantly less likely to separate due to 'other' reasons compared with their counterparts in the social services industry. $^{12}$

The type of employment contract is another job related characteristics that sheds some light into separation patterns. Accordingly, men in full-time employment across the three samples are generally significantly less likely to separate from their job for any of the reasons identified. On the other hand, guest-worker women in full-time 
employment are found to be significantly less likely to 'quit' while no significant effect of being in full-time employment is found for native women.

As stated in Section 2, theories of turnover attach huge importance to a worker's job tenure and pay in predicting the type of separation the worker experiences. The empirical findings in this study provide strong evidence in support of these theoretical predictions. Accordingly, job tenure is found to have a significant negative effect on job separation of any sort for men and women in the two samples. Thus, the likelihood of worker separation due to any of the reasons identified generally declines with job tenure. As would be expected, however, this relationship is reversed eventually as the coefficient estimates of the squared tenure terms indicate. With regards to the effect of the level of wage on separation, the evidence shows that it has a universal and significant negative effect on job separation of any type in the two samples and both for men and women. This is by far the most powerful of the predictors of job separation in this study.

\subsection{Time period and regional characteristics}

Native men in Berlin and adjoining regions and those in Western regions of Germany are found to be significantly less likely to separate due to 'quit' compared with their counterparts in southern regions of Germany. On the other hand, native men in Northern regions are significantly more likely to separate due to 'other' reasons. Guest-worker men in Berlin and adjoining regions are significantly more likely to experience any of the three separations vis-à-vis their counterparts in southern regions while those in northern regions are significantly more likely to separate due to 'quit'. Guest-worker women in Berlin and adjoining regions are also significantly more likely to separate due to 'layoff' and 'quit' compared with their counterparts in the south.

The estimated coefficients relating to the time dummies reinforce the patterns of separations depicted in Figures A1-A4. Accordingly, native men are significantly more likely to separate due to 'quit' and less likely to experience 'layoff' and 'other' reasons in the pre-unification period. Following unification, however, native men are generally significantly less likely to separate due to 'quit' and significantly more likely to separate due to 'other' reasons. This relationship is more or less the same for native women. In contrast, guest-worker men and women who were significantly more likely to separate due to 'quit' in the pre-unification period have become significantly more likely to separate due to 'layoff' and 'other' reasons in the post unification period.

\section{$5.4 \quad$ Unobserved characteristics}

As well as using detailed observable characteristics to predict job separations, the empirical methodology employed in this study accounts for unobserved characteristics that play a part in explaining job separations. As reported in Tables 1 and 2, the unobserved heterogeneity terms are significant in all models estimated, suggesting that failing to account for such factors would lead to biased estimates of the predictors of job separations. In all cases, the reported unobserved heterogeneity terms relate to the location of mass point $1\left(\theta_{1}\right)$ and the corresponding log odds for mass point 1 
$\left(\mathrm{p}_{1}\right){ }^{13}$ The estimated mass points, $\hat{\theta}_{1}$ and $\hat{\theta}_{2}$, are random effects representing two (latent) groups/masses of workers in each model while the associated probabilities, $\hat{\pi}_{1}$ and $\hat{\pi}_{2}$, represent the probabilities that a (unknown) worker's random effect has a value equal to the particular mass point in question. Thus, for example, 80.4 per cent of native men are assumed to belong to the mass represented by a random effect of 0.2460 while the remaining 19.6 are assumed to come from the mass with a random effect of 1.0083 .

\section{Conclusion}

Using the longest panel data set in Europe (SOEP) and employing a MMNL model, this study establishes the nature of job separation in the largest labour market in Europe. It exploits the detailed reasons for job separation reported and the different samples monitored by the SOEP to shed more light into the nature of job separation in Germany. The study not only shows the trends in job separations for different reasons over a period of two decades but it also answers questions relating to the type of workers that are more likely to separate, providing some new insights into job separations in Germany that are hitherto unexplored. Most findings of this study regarding factors that explain job separations are in line with predictions of theories of turnover and previous studies of similar nature. In particular, the study finds that younger workers and women are generally more likely to separate voluntarily while older workers in general and older men in particular are more likely to do so involuntarily. The standard predictors of job separation that relate to firm size, industry of employment, job tenure and wage level are also found to be strong predictors of the types of job separations workers in Germany experience. Accordingly, workers in smaller firms are less likely to be 'stayers' and more likely to experience 'layoffs' vis-à-vis their counterparts in large firms. On the other hand, workers in manufacturing, mining and service provision industries are more likely to separate due to 'layoff' and 'other' reasons compared with their counterparts in the social services industry. Separation in general and 'layoff' in particular is also found to be less of an issue to those with longer job tenure and higher levels of wages, consistent with predictions of theories of job turnover.

Two findings that are particularly worthy of a note are those relating to workers with some form of disability and those from minority groups. The study finds that workers with some form of 'disability' or workers that reported to have been "out of work for more than six weeks due to illness" are more likely to separate from their job involuntarily. The German re-unification and the changes in the patterns of separations observed around the period reveal how 'minorities' fare in a labour market experiencing exogenous shocks. The evidence in this study shows that 'minorities' are more likely to face higher levels of involuntary separations. Men and women workers from the guest-worker sample of the SOEP are found to be significantly more likely to separate involuntarily in the post re-unification period visà-vis their native counterparts. An important implication of the findings in this study is that in the face of a major shock of the sort experienced in Germany, interventions aimed at protecting workers from minority groups might be a policy option worthy of consideration. Absent such affirmative action type interventions, minority workers are likely to bear the brunt of the shock. 


\section{Acknowledgement:}

The data used in this publication was made available to us by the German SocioEconomic Panel Study (SOEP) at the German Institute for Economic Research (DIW Berlin) 
Table 1: Native (west) Germans

\begin{tabular}{|c|c|c|c|c|c|c|}
\hline & \multicolumn{3}{|c|}{ Men } & \multicolumn{3}{|c|}{ Women } \\
\hline & Layoff & Quit & Other & Layoff & Quit & Other \\
\hline \multicolumn{7}{|c|}{ Demographic characteristics } \\
\hline \multirow[t]{2}{*}{ Age $<25$} & -0.061 & 0.175 & 1.388 & -0.230 & 0.124 & 0.862 \\
\hline & $(0.37)$ & $(1.59)$ & $(8.54)^{* *}$ & $(1.32)$ & $(1.24)$ & $(6.19)^{* *}$ \\
\hline \multirow[t]{2}{*}{ Age25-34 } & -0.324 & 0.279 & 0.236 & 0.058 & 0.318 & 1.157 \\
\hline & $(2.81)^{* *}$ & $(4.07)^{* *}$ & $(1.79)$ & $(0.41)$ & $(3.95)^{* *}$ & $(11.76)^{* *}$ \\
\hline \multirow[t]{2}{*}{ Age45-54 } & 0.052 & -0.615 & -0.007 & -0.041 & -0.699 & -0.972 \\
\hline & $(0.37)$ & $(5.93)^{* *}$ & $(0.05)$ & $(0.27)$ & $(6.49)^{* *}$ & $(5.70)^{* *}$ \\
\hline \multirow[t]{2}{*}{ Age $>=55$} & 0.429 & -0.463 & 1.416 & 0.269 & -0.576 & 0.122 \\
\hline & $(2.21)^{*}$ & $(2.91)^{* *}$ & $(9.52)^{* *}$ & $(1.11)$ & $(2.89)^{* *}$ & $(0.61)$ \\
\hline \multirow[t]{2}{*}{ Age $>58$} & 0.185 & 1.058 & 1.445 & 0.433 & 0.677 & 2.679 \\
\hline & $(0.70)$ & $(5.65)^{* *}$ & $(11.34)^{* *}$ & $(1.28)$ & $(2.32)^{*}$ & $(13.78)^{* *}$ \\
\hline \multirow[t]{2}{*}{ Single } & 0.073 & 0.100 & 0.223 & 0.025 & -0.117 & -0.773 \\
\hline & $(0.66)$ & $(1.54)$ & $(2.29)^{*}$ & $(0.20)$ & $(1.45)$ & $(7.83)^{* *}$ \\
\hline \multirow[t]{2}{*}{ Own house } & -0.247 & -0.107 & -0.135 & -0.461 & -0.187 & -0.303 \\
\hline & $(2.78)^{* *}$ & $(1.88)^{*}$ & $(1.85)^{*}$ & $(4.22)^{* *}$ & $(3.06)^{* *}$ & $(4.10)^{* *}$ \\
\hline \multirow[t]{2}{*}{ Working partner } & -0.077 & -0.014 & -0.252 & -0.357 & -0.078 & -0.129 \\
\hline & $(0.81)$ & $(0.24)$ & $(3.09)^{* *}$ & $(2.99)^{* *}$ & $(1.06)$ & $(1.57)$ \\
\hline \multirow[t]{2}{*}{ Disable } & 0.779 & 0.631 & 1.069 & 0.867 & 0.542 & 1.036 \\
\hline & $(5.06)^{* *}$ & $(5.68)^{* *}$ & $(8.88)^{* *}$ & $(4.97)^{* *}$ & $(4.44)^{* *}$ & $(8.27)^{* *}$ \\
\hline \multicolumn{7}{|c|}{ Required training for the job } \\
\hline \multirow[t]{2}{*}{ None/introductory } & -0.185 & -0.096 & -0.118 & -0.167 & -0.107 & -0.361 \\
\hline & $(1.24)$ & $(0.96)$ & $(0.78)$ & $(1.10)$ & $(1.06)$ & $(2.74)^{* *}$ \\
\hline \multirow[t]{2}{*}{ On the job training } & -0.004 & -0.201 & -0.242 & -0.198 & -0.001 & -0.158 \\
\hline & $(0.03)$ & $(2.48)^{*}$ & $(2.27)^{*}$ & $(1.31)$ & $(0.01)$ & $(1.41)$ \\
\hline \multirow[t]{2}{*}{ Vocational training } & -0.295 & 0.039 & -0.015 & 0.004 & 0.339 & 0.693 \\
\hline & $(1.51)$ & $(0.44)$ & $(0.11)$ & $(0.01)$ & $(2.42)^{*}$ & $(4.81)^{* *}$ \\
\hline \multirow[t]{2}{*}{ College level training } & 0.279 & 0.278 & 0.158 & 0.828 & 0.771 & 0.659 \\
\hline & (1.13) & $(2.29)^{*}$ & $(0.96)$ & $(3.17)^{* *}$ & $(5.07)^{* *}$ & $(4.20)^{* *}$ \\
\hline \multicolumn{7}{|l|}{ Occupation } \\
\hline Unskilled & 0.162 & 0.107 & -0.321 & -0.127 & -0.056 & 0.029 \\
\hline
\end{tabular}


Semi-skilled

\section{Skilled}

Missing occupation

Firm size

Firm size $<20$

Firm size $<200$

Firm size $>2000$

Industry

Manufacturing

Wholesale trade, hotel \&res

Mining \& construction

Transport, finance, real estate

Missing industry

Working full-time

Job tenure

Tenure square/100

Log of real hourly wage

$\begin{array}{cccccc}(0.98) & (0.93) & (1.90)^{*} & (1.03) & (0.73) & (0.30) \\ 0.218 & -0.054 & -0.128 & -0.010 & -0.063 & 0.113 \\ (1.51) & (0.54) & (0.86) & (0.05) & (0.51) & (0.74) \\ 0.007 & -0.173 & -0.014 & 0.039 & 0.185 & 0.013 \\ (0.06) & (2.37)^{*} & (0.14) & (0.17) & (1.38) & (0.06) \\ -1.587 & -0.714 & -0.200 & -1.901 & -1.150 & -0.153 \\ (5.52)^{* *} & (6.22)^{* *} & (1.60) & (6.10)^{* *} & (6.72)^{* *} & (1.17) \\ & & & & & \\ 0.867 & 0.254 & -0.179 & 0.586 & 0.165 & -0.464 \\ (8.27)^{* *} & (3.54)^{* *} & (1.72)^{*} & (4.85)^{* *} & (2.41)^{*} & (5.22)^{* *} \\ 0.397 & 0.042 & -0.143 & 0.288 & -0.011 & -0.288 \\ (3.78)^{* *} & (0.64) & (1.69)^{*} & (2.41)^{*} & (0.16) & (3.56)^{* *} \\ 0.492 & 0.113 & 1.194 & -0.294 & -0.304 & -0.615 \\ (1.64) & (0.56) & (4.39)^{* *} & (0.81) & (1.62) & (2.26)^{*} \\ & & & & & \\ 0.499 & -0.073 & -0.419 & 0.716 & 0.055 & -0.290 \\ (3.27)^{* *} & (0.87) & (4.10)^{* *} & (4.97)^{* *} & (0.66) & (2.88)^{* *} \\ 0.480 & 0.197 & -0.399 & 0.811 & 0.285 & -0.563 \\ (2.78)^{* *} & (1.92)^{*} & (3.01)^{* *} & (5.92)^{* *} & (3.47)^{* *} & (5.46)^{* *} \\ 0.875 & 0.003 & -0.456 & 1.018 & -0.166 & -0.265 \\ (5.16)^{* *} & (0.03) & (3.32)^{* *} & (3.46)^{* *} & (0.64) & (1.03) \\ 0.402 & 0.320 & -0.280 & 0.696 & 0.343 & -0.186 \\ (2.31)^{*} & (3.43)^{* *} & (2.43)^{*} & (4.34)^{* *} & (3.83)^{* *} & (1.80)^{*} \\ 0.379 & -0.438 & -1.277 & 0.906 & 0.013 & -0.256 \\ (1.44) & (2.72)^{* *} & (4.94)^{* *} & (3.62)^{* *} & (0.09) & (1.17) \\ -0.473 & -0.426 & -1.062 & -0.261 & -0.037 & -0.099 \\ (2.51)^{*} & (3.77)^{* *} & (6.72)^{* *} & (2.19)^{*} & (0.50) & (1.15) \\ -0.161 & -0.144 & -0.110 & -0.183 & -0.160 & -0.103 \\ (10.46)^{* *} & (14.17)^{* *} & (8.97)^{* *} & (9.22)^{* *} & (12.34)^{* *} & (7.60)^{* *} \\ 0.344 & 0.298 & 0.274 & 0.434 & 0.346 & 0.274 \\ (8.69)^{* *} & (10.22)^{* *} & (9.53)^{* *} & (7.32)^{* *} & (7.77)^{* *} & (6.67)^{* *} \\ -0.918 & -0.285 & -0.867 & -1.074 & -0.408 & -0.929 \\ (11.53)^{* *} & (6.57)^{* *} & (12.99)^{* *} & (14.55)^{* *} & (8.72)^{* *} & (16.07)^{* *} \\ & & & & & \end{array}$


Region

Berlin, Brandenberg, Saxony-anh, Trundia, Saxony (Berlin \& adjoining regions)

Schleswig-H., Hamburg, Lower Saxony, Bremen, Mecklen. (Northern regions)

North Rhine-West., Hesse, Rhinel.-palatinate, saarl. (Western regions)

Year/time dummies

1986-1987

1988-1989

1990-1993

1994-1996

1997-1999

2000-2002

Mass point $1\left(\theta_{1}\right)$ (location for class 1$)$

Log odds for class $1\left(p_{1}\right)$

Log-likelihood

Predicted probabilities

No. of observations (level 1 units)

\begin{tabular}{|c|c|c|c|c|c|}
\hline $\begin{array}{l}0.178 \\
(0.76)\end{array}$ & $\begin{array}{c}-0.248 \\
(1.65)^{*}\end{array}$ & $\begin{array}{l}0.201 \\
(1.15)\end{array}$ & $\begin{array}{c}0.378 \\
(1.68)^{*}\end{array}$ & $\begin{array}{c}-0.390 \\
(2.44)^{*}\end{array}$ & $\begin{array}{l}-0.244 \\
(1.31)\end{array}$ \\
\hline 0.225 & -0.000 & 0.218 & -0.062 & -0.163 & -0.258 \\
\hline$(1.88)^{*}$ & $(0.01)$ & $(2.14)^{*}$ & $(0.43)$ & $(1.91)^{*}$ & $(2.50)^{*}$ \\
\hline-0.048 & -0.158 & 0.086 & -0.078 & -0.228 & -0.262 \\
\hline$(0.47)$ & $(2.56)^{*}$ & (1.09) & $(0.66)$ & $(3.39)^{* *}$ & $(3.33)^{* *}$ \\
\hline-0.501 & 0.114 & 0.014 & -0.219 & 0.222 & -0.564 \\
\hline$(3.07)^{* *}$ & (1.35) & $(0.09)$ & (1.16) & (2.27)* & $(3.01)^{* *}$ \\
\hline-0.965 & 0.165 & 0.190 & -0.197 & 0.438 & -0.249 \\
\hline$(4.81)^{* *}$ & $(1.94)^{*}$ & (1.21) & (0.93) & $(4.42)^{* *}$ & (1.44) \\
\hline-0.053 & -0.649 & 0.780 & 0.258 & -0.296 & 1.143 \\
\hline (0.39) & $(7.48)^{* *}$ & $(6.07)^{* *}$ & (1.61) & $(3.01)^{* *}$ & $(9.56)^{* *}$ \\
\hline 0.350 & -0.689 & 1.053 & 0.405 & -0.330 & 1.051 \\
\hline$(2.58) * *$ & $(6.85)^{* *}$ & $(7.50)^{* *}$ & $(2.35)^{*}$ & $(2.99)^{* *}$ & $(8.09)^{* *}$ \\
\hline 0.035 & -0.705 & 0.921 & 0.053 & -0.457 & 1.252 \\
\hline$(0.23)$ & $(7.04)^{* *}$ & $(6.14)^{* *}$ & $(0.29)$ & $(3.91)^{* *}$ & $(9.62)^{* *}$ \\
\hline-0.043 & -0.905 & 0.748 & 0.152 & -0.578 & 1.079 \\
\hline$(0.29)$ & $(8.47)^{* *}$ & $(4.96)^{* *}$ & $(0.89)$ & $(4.93)^{* *}$ & $(8.33)^{* *}$ \\
\hline-0.246 & & & -0.252 & & \\
\hline$(3.12)^{* *}$ & & & $(2.64)^{* *}$ & & \\
\hline 1.410 & & & 1.345 & & \\
\hline$(2.71)^{* *}$ & & & $(2.05)^{*}$ & & \\
\hline-13340.24 & & & -11151.42 & & \\
\hline .0244298 & .0713411 & .0385508 & .0258708 & 0918833 & .0595152 \\
\hline 30096 & & & 20491 & & \\
\hline 3990 & & & 3235 & & \\
\hline
\end{tabular}

No. of individuals (level 2 units)

Absolute value of $\mathrm{z}$ statistics in parentheses

* significant at 10\%; * significant at 5\%; ** significant at $1 \%$ 
Table 2: Guest-workers

\begin{tabular}{|c|c|c|c|c|c|c|}
\hline & \multicolumn{3}{|c|}{ Men } & \multicolumn{3}{|c|}{ Women } \\
\hline & Layoff & Quit & Other & Layoff & Quit & Other \\
\hline \multicolumn{7}{|c|}{ Demographic characteristics } \\
\hline \multirow[t]{2}{*}{ Age $<25$} & 0.275 & 0.406 & 0.435 & -0.078 & 0.849 & 1.702 \\
\hline & $(1.41)$ & $(2.12)^{*}$ & $(1.60)$ & $(0.35)$ & $(3.94)^{* *}$ & $(6.26)^{* *}$ \\
\hline \multirow[t]{2}{*}{ Age25-34 } & -0.053 & 0.454 & -0.172 & -0.228 & 0.658 & 1.533 \\
\hline & $(0.33)$ & $(3.24)^{* *}$ & $(0.72)$ & $(1.25)$ & $(3.78)^{* *}$ & $(7.17)^{* *}$ \\
\hline \multirow[t]{2}{*}{ Age45-54 } & 0.002 & -0.458 & 0.215 & 0.285 & -0.587 & -0.256 \\
\hline & $(0.01)$ & $(2.45)^{*}$ & $(0.85)$ & $(1.67)^{*}$ & $(2.76)^{* *}$ & $(0.92)$ \\
\hline \multirow[t]{2}{*}{ Age $>=55$} & 0.209 & -0.033 & 1.506 & 0.327 & -0.630 & -0.077 \\
\hline & $(0.81)$ & $(0.12)$ & $(5.69) * *$ & (1.09) & $(1.70)^{*}$ & $(0.19)$ \\
\hline \multirow[t]{2}{*}{ Age $>58$} & 0.460 & 0.114 & 1.429 & 0.316 & 0.544 & 3.116 \\
\hline & $(1.29)$ & $(0.28)$ & $(5.40)^{* *}$ & $(0.58)$ & $(0.82)$ & $(6.80)^{* *}$ \\
\hline \multirow[t]{2}{*}{ Single } & 0.029 & 0.250 & -0.002 & -0.220 & -0.110 & -0.894 \\
\hline & $(0.21)$ & $(2.08)^{*}$ & $(0.01)$ & $(1.03)$ & $(0.55)$ & $(4.41)^{* *}$ \\
\hline \multirow[t]{2}{*}{ Own house } & -0.524 & 0.145 & -0.182 & -0.225 & 0.097 & 0.170 \\
\hline & $(2.45)^{*}$ & $(1.02)$ & $(0.85)$ & $(1.05)$ & $(0.50)$ & $(0.89)$ \\
\hline \multirow[t]{2}{*}{ Working partner } & -0.185 & 0.006 & -0.377 & 0.033 & 0.073 & -0.312 \\
\hline & $(1.58)$ & $(0.06)$ & $(2.14)^{*}$ & $(0.20)$ & $(0.42)$ & $(1.82)$ \\
\hline \multirow[t]{2}{*}{ Disable } & 0.755 & 0.044 & 0.713 & 0.902 & 0.945 & 0.988 \\
\hline & $(4.49)^{* *}$ & $(0.21)$ & $(3.37)^{* *}$ & $(4.28)^{* *}$ & $(5.19)^{* *}$ & $(4.58) * *$ \\
\hline \multicolumn{7}{|c|}{ Required training for the job } \\
\hline \multirow[t]{2}{*}{ None/introductory } & -0.125 & -0.207 & -0.426 & -0.598 & -0.157 & -0.279 \\
\hline & $(0.73)$ & $(1.46)$ & $(2.02)^{*}$ & $(2.72)^{* *}$ & $(0.85)$ & $(1.31)$ \\
\hline \multirow[t]{2}{*}{ On the job training } & -0.368 & -0.124 & -0.557 & -0.634 & -0.338 & -0.263 \\
\hline & $(2.11)^{*}$ & $(0.89)$ & $(2.65)^{* *}$ & $(2.29)^{*}$ & $(1.52)$ & $(1.11)$ \\
\hline \multirow[t]{2}{*}{ Vocational training } & 0.365 & -0.049 & -0.071 & -0.557 & 0.464 & 0.757 \\
\hline & $(0.76)$ & $(0.12)$ & $(0.13)$ & $(0.56)$ & $(0.91)$ & $(1.32)$ \\
\hline \multirow{2}{*}{ College level training } & 0.930 & 0.828 & 0.373 & 0.965 & 1.245 & -0.173 \\
\hline & $(3.33)^{* *}$ & $(3.03)^{* *}$ & $(1.02)$ & $(2.49)^{*}$ & $(4.36)^{* *}$ & $(0.42)$ \\
\hline \multicolumn{7}{|l|}{ Occupation } \\
\hline Unskilled & 0.431 & 0.085 & 0.009 & 0.072 & -0.236 & -0.066 \\
\hline
\end{tabular}


Semi-skilled

\section{Skilled}

Missing occupation

Firm size

Firm size $<20$

Firm size $<200$

Firm size $>2000$

Industry

Manufacturing

Wholesale trade, hotel \&res

Mining \& construction

Transport, finance, real estate

Missing industry

Working full-time

Job tenure

Tenure square/100

Log of real hourly wage

\begin{tabular}{|c|c|c|c|c|c|}
\hline$(1.76)^{*}$ & $(0.45)$ & $(0.03)$ & $(0.30)$ & (1.28) & $(0.30)$ \\
\hline 0.357 & -0.032 & 0.292 & 0.118 & -0.301 & -0.111 \\
\hline (1.52) & (0.18) & (1.16) & $(0.45)$ & (1.44) & $(0.45)$ \\
\hline 0.176 & 0.079 & -0.300 & -0.364 & -0.562 & -0.716 \\
\hline$(0.80)$ & $(0.47)$ & (1.20) & (0.89) & $(1.77)^{*}$ & $(1.68)^{*}$ \\
\hline-2.174 & -1.427 & -0.287 & -1.827 & -2.081 & -0.529 \\
\hline$(5.20)^{* *}$ & $(3.78)^{* *}$ & $(0.71)$ & $(3.51)^{* *}$ & $(5.07)^{* *}$ & (1.24) \\
\hline 0.573 & 0.714 & 0.095 & 0.354 & 0.144 & -0.272 \\
\hline$(4.02)^{* *}$ & $(6.00)^{* *}$ & $(0.52)$ & $(1.87)^{*}$ & (0.98) & (1.60) \\
\hline 0.399 & 0.415 & -0.178 & 0.364 & 0.112 & -0.148 \\
\hline$(3.18)^{* *}$ & $(3.85)^{* *}$ & (1.09) & $(2.22)^{*}$ & $(0.78)$ & $(0.94)$ \\
\hline-0.014 & 0.181 & -0.193 & -0.133 & -0.514 & -0.325 \\
\hline$(0.05)$ & $(0.61)$ & $(0.43)$ & $(0.30)$ & (1.62) & $(0.64)$ \\
\hline 0.024 & -0.386 & -0.448 & 0.859 & 0.002 & -0.362 \\
\hline (0.09) & (1.51) & $(1.71)^{*}$ & $(4.08)^{* *}$ & $(0.01)$ & $(1.95)^{*}$ \\
\hline 0.130 & -0.050 & -0.623 & 0.785 & 0.255 & -0.574 \\
\hline$(0.42)$ & (0.19) & $(1.88)^{*}$ & $(3.53)^{* *}$ & (1.47) & $(2.83)^{* *}$ \\
\hline 0.394 & -0.375 & -0.378 & 1.698 & 0.870 & 0.161 \\
\hline (1.39) & (1.40) & $(1.26)$ & $(2.90) * *$ & (1.57) & $(0.14)$ \\
\hline-0.109 & 0.085 & -0.580 & 0.452 & 0.178 & -0.480 \\
\hline$(0.35)$ & $(0.32)$ & $(1.72)^{*}$ & $(1.67)^{*}$ & (0.87) & $(2.07)^{*}$ \\
\hline-0.186 & -0.716 & -0.143 & 0.494 & -0.037 & -0.547 \\
\hline$(0.58)$ & $(2.26)^{*}$ & $(0.36)$ & (1.63) & $(0.14)$ & (1.62) \\
\hline-0.580 & -0.729 & -1.415 & -0.054 & -0.455 & 0.193 \\
\hline$(2.08)^{*}$ & $(3.29)^{* *}$ & $(4.40)^{* *}$ & $(0.32)$ & $(3.24)^{* *}$ & (1.04) \\
\hline-0.197 & -0.196 & -0.220 & -0.197 & -0.122 & -0.146 \\
\hline$(9.03)^{* *}$ & $(9.49) * *$ & $(7.66)^{* *}$ & $(7.25)^{* *}$ & $(4.97)^{* *}$ & $(5.05) * *$ \\
\hline 0.548 & 0.537 & 0.605 & 0.500 & 0.343 & 0.461 \\
\hline$(7.38)^{* *}$ & $(7.33)^{* *}$ & $(7.12)^{* *}$ & $(5.78)^{* *}$ & $(3.99)^{* *}$ & $(5.41)^{* *}$ \\
\hline-0.842 & -0.511 & -0.874 & -1.025 & -0.786 & -1.330 \\
\hline$(6.90)^{* *}$ & $(5.46)^{* *}$ & $(6.72)^{* *}$ & $(7.66)^{* *}$ & $(6.66)^{* *}$ & $(10.16)^{* *}$ \\
\hline
\end{tabular}


Region

Berlin, Brandenberg, Saxony-anh, Trundia, Saxony (Berlin \& adjoining regions)

Schleswig-H., Hamburg, Lower Saxony, Bremen, Mecklen. (Northern regions)

North Rhine-West., Hesse, Rhinel.-palatinate, saarl. (Western regions)

\begin{tabular}{|c|c|c|c|c|c|}
\hline $\begin{array}{c}1.295 \\
(4.45)^{* *}\end{array}$ & $\begin{array}{c}0.568 \\
(1.88)^{*}\end{array}$ & $\begin{array}{c}0.891 \\
(2.37)^{*}\end{array}$ & $\begin{array}{c}0.937 \\
(3.39)^{* *}\end{array}$ & $\begin{array}{c}0.573 \\
(1.74)^{*}\end{array}$ & $\begin{array}{l}0.059 \\
(0.13)\end{array}$ \\
\hline-0.043 & 0.342 & 0.064 & -0.199 & -0.002 & -0.122 \\
\hline$(0.20)$ & $(2.19) *$ & $(0.26)$ & $(0.84)$ & $(0.01)$ & $(0.50)$ \\
\hline-0.070 & -0.074 & 0.017 & -0.258 & -0.148 & -0.190 \\
\hline$(0.60)$ & $(0.78)$ & $(0.12)$ & $(1.73)^{*}$ & (1.14) & $(1.36)$ \\
\hline 0.178 & 0.545 & 0.854 & -0.239 & 0.494 & -0.858 \\
\hline (0.97) & $(3.38)^{* *}$ & $(2.56)^{*}$ & $(0.88)$ & $(2.30)^{*}$ & $(1.90)^{*}$ \\
\hline-0.326 & 0.329 & 0.315 & -0.146 & 0.731 & -0.320 \\
\hline (1.52) & $(2.05)^{*}$ & $(0.83)$ & $(0.52)$ & $(3.46)^{* *}$ & $(0.85)$ \\
\hline 0.390 & -0.147 & 1.763 & 0.486 & 0.091 & 1.470 \\
\hline$(2.31)^{*}$ & $(0.95)$ & $(6.23)^{* *}$ & $(2.09)^{*}$ & $(0.43)$ & $(6.17)^{* *}$ \\
\hline 0.609 & -0.186 & 1.927 & 0.442 & 0.091 & 1.799 \\
\hline$(3.23)^{* *}$ & (1.07) & $(6.39)^{* *}$ & $(1.67)^{*}$ & (0.38) & $(6.99)^{* *}$ \\
\hline 0.465 & 0.002 & 2.150 & 0.251 & 0.238 & 1.859 \\
\hline$(2.25)^{*}$ & $(0.01)$ & $(6.78)^{* *}$ & $(0.83)$ & (1.00) & $(7.30)^{* *}$ \\
\hline 0.411 & -0.220 & 1.496 & 0.295 & 0.048 & 1.206 \\
\hline$(1.93)^{*}$ & (1.14) & $(4.61)^{* *}$ & $(1.10)$ & $(0.20)$ & $(4.85)^{* *}$ \\
\hline-0.988 & & & -0.248 & & \\
\hline$(2.18)^{*}$ & & & $(2.25)^{*}$ & & \\
\hline-0.545 & & & 1.484 & & \\
\hline$(0.84)$ & & & $(2.13)^{*}$ & & \\
\hline-5224.27 & & & -3436.77 & & \\
\hline .0414908 & .0588116 & .0263155 & .0425452 & .065693 & .0473984 \\
\hline 12167 & & & 6863 & & \\
\hline 1838 & & & 1215 & & \\
\hline
\end{tabular}

Year/time dummies

1986-1987

1988-1989

1990-1993

1994-1996

1997-1999

$2000-2002$

Mass point $1\left(\theta_{1}\right)$ (location for class 1$)$

Log odds for class $1\left(p_{1}\right)$

Log-likelihood

Predicted probabilities

No. of observations (level 1 units)

No. of individuals (level 2 units)

1215

Absolute value of $\mathrm{z}$ statistics in parentheses

* significant at $10 \%$; * significant at 5\%; ** significant at $1 \%$ 


\section{Appendix}

Table A1: Reasons for job separations reported in each wave of the SOEP

\section{Layoff}

Notice given by employer

Dismissal/dismissed or

had been advised to resign

Terminated by employer

Company/place of work/ closed

down, job was cut, lack

of work, laid off

\section{Quit}

Resigned

Had to quit my job for personal

reasons

Beginning of further

training/retraining/education

Wanted to look for another job

It was no longer financially

necessary for me to work

By my own request was

transferred within the firm

Sent to another position

by the firm

Argument with boss

Moved, company transferred

employee

Marriage/married

Children or child care responsibilities

Care of other persons (sick,

aged, disabled)

Unfit to work/disabled/incapacitated

/other health reasons

Wanted a change in career

Found a better job

No longer needed to work

Quit for other reasons

Other

Mutual agreement

Reaching retirement age/

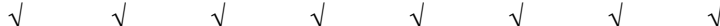

$1992-1993$

$\begin{array}{llllllllll}1994 & 1995 & 1996 & 1997 & 1998 & 1999 & 2000 & 2001 & 2002 & 2003\end{array}$ 


$\begin{array}{llllll}\sqrt{ } & \sqrt{ } & \sqrt{ } & \sqrt{ } & \sqrt{ } & \sqrt{ } \\ \sqrt{ } & \sqrt{ } & \sqrt{ } & \sqrt{ } & \sqrt{ } & \sqrt{ } \\ \sqrt{ } & \sqrt{ } & \sqrt{ } & \sqrt{ } & \sqrt{ } & \sqrt{ } \\ \sqrt{ } & \sqrt{ } & \sqrt{ } & \sqrt{ } & \sqrt{ } & \sqrt{ }\end{array}$

$\sqrt{ }$
$\sqrt{ }$
$\sqrt{ }$
$\sqrt{ }$

$\begin{array}{lllllll}\sqrt{ } & \sqrt{ } & \sqrt{ } & \sqrt{ } & \sqrt{ } & \sqrt{ } & \sqrt{ } \\ \sqrt{ } & \sqrt{ } & \sqrt{ } & \sqrt{ } & \sqrt{ } & \sqrt{ } & \sqrt{ } \\ & & & & & & \\ \sqrt{ } & \sqrt{ } & \sqrt{ } & \sqrt{ } & \sqrt{ } & \sqrt{ } & \sqrt{ }\end{array}$

\section{Notes:}

1. The tick ' $\sqrt{ }$ ' marks show that the particular reason(s) for job separation listed on the left hand side were monitored in the year heading each column. No tick mark (empty cell) indicates that the particular reason was not monitored in the year in question.

2. Although the question route has not been identical from year to year, the typical question monitoring whether one has experienced a job separation goes as follows. First, those currently unemployed would be asked if they have lost a job since the previous interview while those currently in employment would be asked if their job situation has changed over the same period. Then, respondents would be asked as to which of the detailed reasons (monitored in a particular year, i.e., those marked by a ' $\sqrt{ }$ ' would apply to the separation they have experienced, if they have.

3. The reasons for job separation (column 1) have been re-classified into 'Layoff', 'Quit' and 'Other' separations. Because some waves monitored fewer reasons than others, the reasons making up 'Layoff', 'Quit' and 'Other' vary from year to year. There are, for example, more reasons making up 'Quit' and 'Other' separations between 1985 and 1990. However, most of these reasons are recorded not as main reasons but as contributing factors, since there are two questions monitoring reasons for job separations during this period. The two questions are: a) 'why did you leave this job? Which one of the following applies to you?' And b) 'which of the following reasons played a role in you giving up your last position? Please indicate all that apply'. The assumption made in re-classifying the reasons is that where some reasons are not monitored specifically in a particular year, they are subsumed under other reasons monitored in the year in question. This, however, appears to be a strong assumption, particularly for 'quits' in Samples A and B, if we look at the plots of cases (their percentages) shown in the appendix. Nonetheless, the huge dip in the proportion of quits in the immediate pre-unification period is compatible with the strong possibility that workers would be less willing to quit their job in the wake of a re-unification that would make labour market conditions tougher.

4. The reasons for job separations in this table run up to 2003 while the period covered by the empirical modelling and the plots run only up to 2002. This is due to the lagging of the 'reason' variable so a particular reason for separation monitored at the date of the interview relates to the job held in the preceding year, rather than the one held at the date of interview if the worker is in employment then, or the last job for those currently not in work. This approach rules out multiple separations in between interviews. 
Table A2: LR Tests for Combining Alternatives Categories.

\begin{tabular}{|c|c|c|c|c|c|c|}
\hline \multicolumn{7}{|c|}{ Native (west) Germans } \\
\hline \multirow[b]{2}{*}{ Categories tested } & \multicolumn{3}{|c|}{ Men $(\mathrm{N}=30096)$} & \multicolumn{3}{|c|}{ Women $(\mathrm{N}=20491)$} \\
\hline & Chi2 & $\mathrm{df}$ & $\mathrm{P}>$ Chi2 & Chi2 & $\mathrm{df}$ & $\mathrm{P}>$ Chi2 \\
\hline $1 \& 2$ & 530.45 & 38 & 0.000 & 271.43 & 38 & 0.000 \\
\hline $1 \& 3$ & 687.46 & 38 & 0.000 & 573.26 & 38 & 0.000 \\
\hline $1 \& 4$ & 935.44 & 38 & 0.000 & 530.61 & 38 & 0.000 \\
\hline $2 \& 3$ & 1138.03 & 38 & 0.000 & 1027.88 & 38 & 0.000 \\
\hline $2 \& 4$ & 1802.45 & 38 & 0.000 & 1344.29 & 38 & 0.000 \\
\hline $3 \& 4$ & 1835.75 & 38 & 0.000 & 1484.52 & 38 & 0.000 \\
\hline \multicolumn{7}{|l|}{ Guest-workers } \\
\hline & \multicolumn{3}{|c|}{ Men $(\mathrm{N}=12167)$} & \multicolumn{3}{|c|}{ Women $(\mathrm{N}=6863)$} \\
\hline Categories tested & Chi2 & $\mathrm{df}$ & $\mathrm{P}>$ Chi2 & Chi2 & $\mathrm{df}$ & $\mathrm{P}>$ Chi2 \\
\hline $1 \& 2$ & 163.12 & 38 & 0.000 & 131.32 & 38 & 0.000 \\
\hline $1 \& 3$ & 202.54 & 38 & 0.000 & 259.15 & 38 & 0.000 \\
\hline $1 \& 4$ & 479.75 & 38 & 0.000 & 233.18 & 38 & 0.000 \\
\hline $2 \& 3$ & 351.57 & 38 & 0.000 & 282.88 & 38 & 0.000 \\
\hline $2 \& 4$ & 784.01 & 38 & 0.000 & 379.96 & 38 & 0.000 \\
\hline $3 \& 4$ & 520.65 & 38 & 0.000 & 529.60 & 38 & 0.000 \\
\hline
\end{tabular}

1. Hote: All coefficients except intercepts associated with a given pair of alternatives are 0 (i.e., alternatives can be collapsed).

2. These tests are based on homogeneous specifications of the MNL models. 


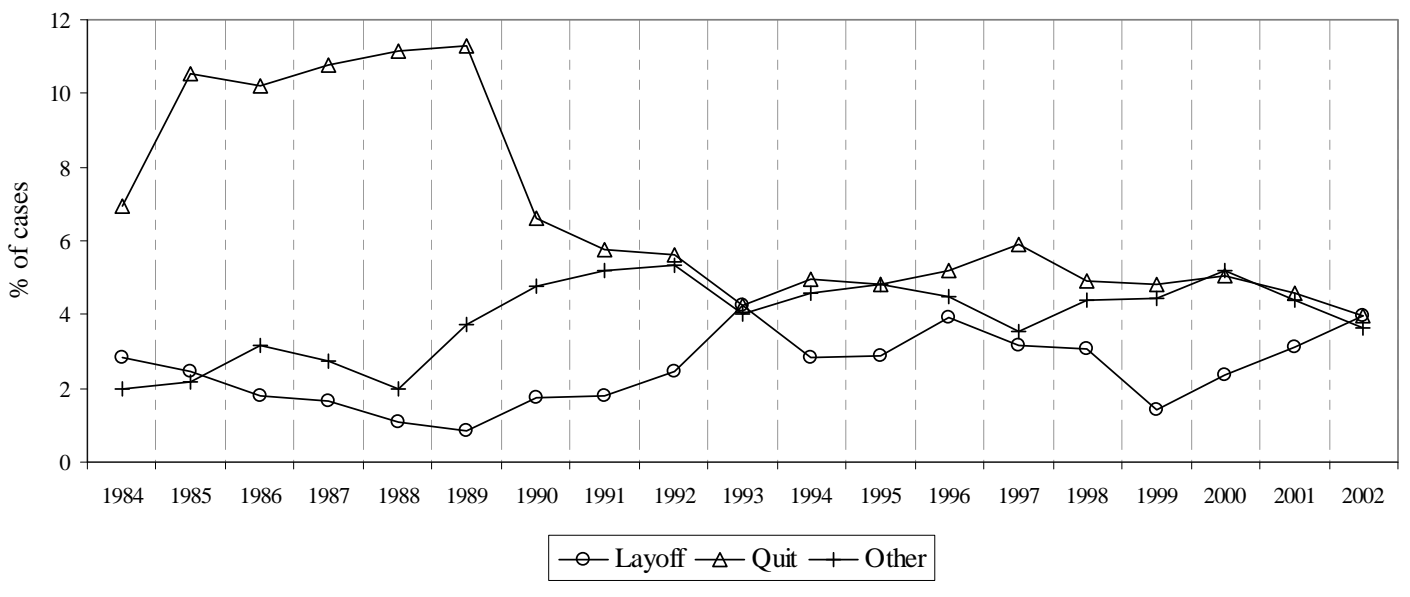

Figure A1: Job separations, native (west) Germans, men (1984-2002) 


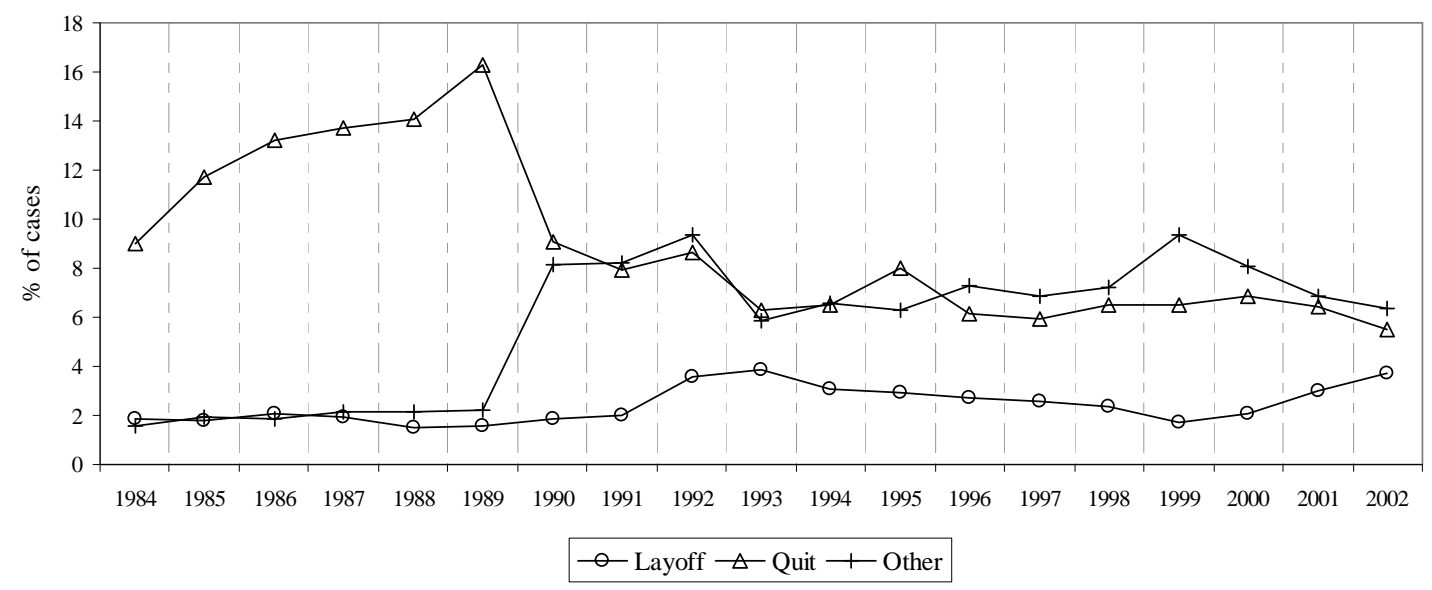

Figure A2: Job separations, native (west) Germans, women (1984-2002) 


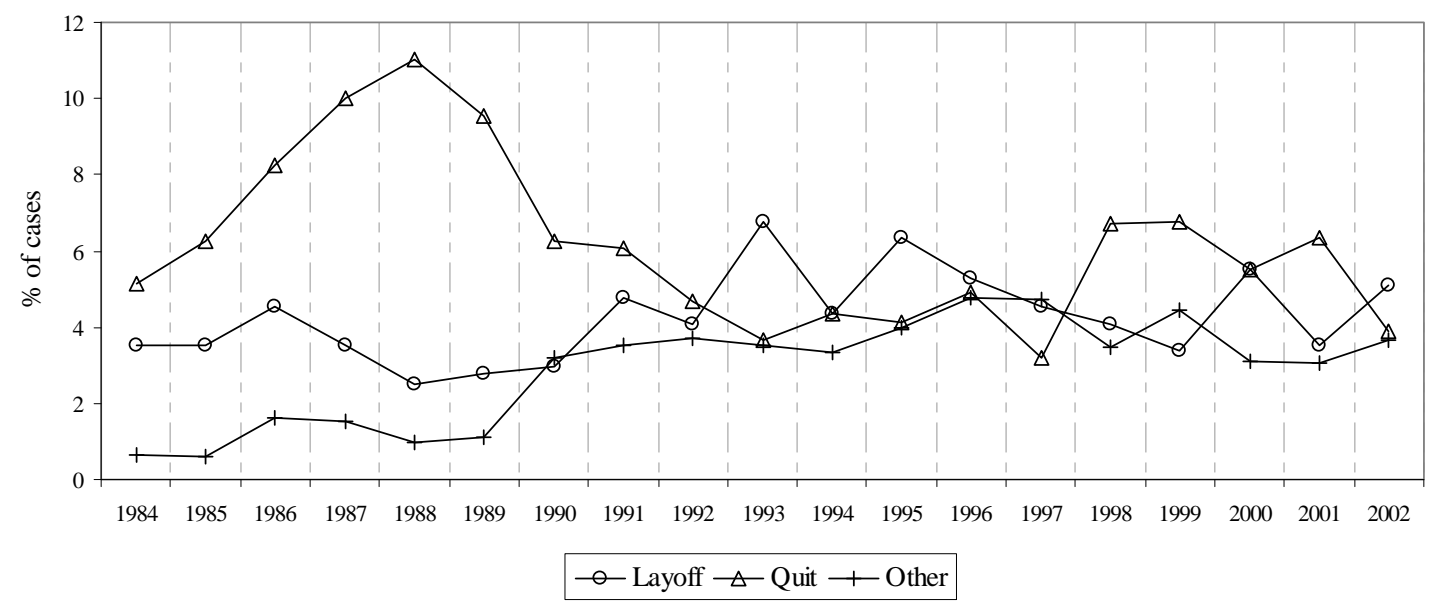

Figure A3: Job separations, guest-workers, men (1984-2002) 


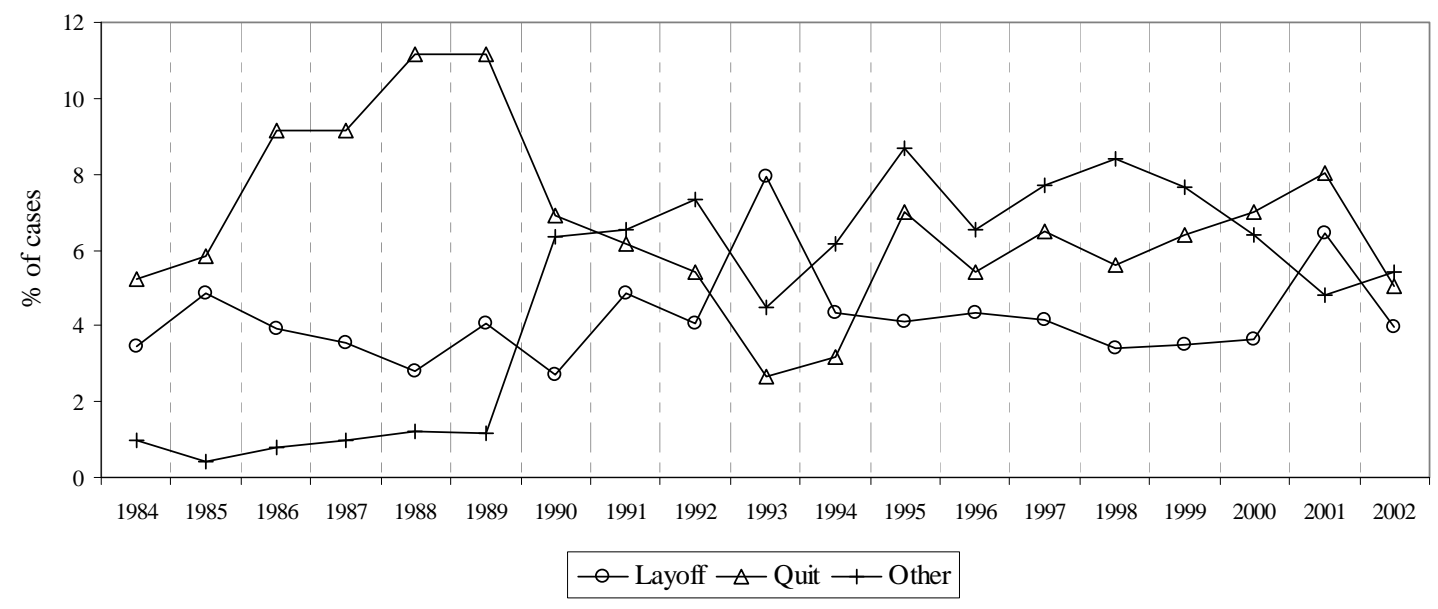

Figure A4: Job separations, guest-workers, women (1984-2002) 
Descriptive characteristics of samples, separately by gender and reason category

Table A3: Native (west) Germans

\begin{tabular}{|c|c|c|c|c|c|c|c|c|c|c|c|c|c|c|c|c|}
\hline & \multicolumn{8}{|c|}{ Men } & \multicolumn{8}{|c|}{ Women } \\
\hline & \multicolumn{2}{|c|}{ Layoff } & \multicolumn{2}{|c|}{ Quit } & \multicolumn{2}{|c|}{ Other } & \multicolumn{2}{|c|}{ Stayer } & \multicolumn{2}{|c|}{ Layoff } & \multicolumn{2}{|c|}{ Quit } & \multicolumn{2}{|c|}{ Other } & \multicolumn{2}{|c|}{ Stayer } \\
\hline & Mean & $\begin{array}{l}\text { Std. } \\
\text { dev }\end{array}$ & Mean & $\begin{array}{l}\text { Std. } \\
\text { dev }\end{array}$ & Mean & $\begin{array}{l}\text { Std. } \\
\text { dev }\end{array}$ & Mean & $\begin{array}{l}\text { Std. } \\
\text { dev }\end{array}$ & Mean & $\begin{array}{l}\text { Std. } \\
\text { dev }\end{array}$ & Mean & $\begin{array}{l}\text { Std. } \\
\text { dev }\end{array}$ & Mean & $\begin{array}{l}\text { Std. } \\
\text { dev }\end{array}$ & Mean & $\begin{array}{l}\text { Std. } \\
\text { dev }\end{array}$ \\
\hline \multicolumn{17}{|c|}{ Demographic characteristics } \\
\hline Age $<25$ & 0.179 & 0.384 & 0.178 & 0.383 & 0.332 & 0.471 & 0.073 & 0.260 & 0.210 & 0.407 & 0.268 & 0.443 & 0.218 & 0.413 & 0.129 & 0.335 \\
\hline Age25-34 & 0.321 & 0.467 & 0.461 & 0.499 & 0.203 & 0.402 & 0.281 & 0.449 & 0.313 & 0.464 & 0.390 & 0.488 & 0.456 & 0.498 & 0.268 & 0.443 \\
\hline Age35-44 & 0.227 & 0.419 & 0.215 & 0.411 & 0.087 & 0.282 & 0.285 & 0.451 & 0.212 & 0.409 & 0.220 & 0.415 & 0.114 & 0.318 & 0.270 & 0.444 \\
\hline Age45-54 & 0.167 & 0.373 & 0.086 & 0.280 & 0.073 & 0.261 & 0.252 & 0.434 & 0.182 & 0.386 & 0.090 & 0.286 & 0.046 & 0.209 & 0.246 & 0.431 \\
\hline Age $>=55$ & 0.106 & 0.308 & 0.060 & 0.238 & 0.305 & 0.461 & 0.109 & 0.312 & 0.084 & 0.277 & 0.032 & 0.176 & 0.167 & 0.373 & 0.086 & 0.281 \\
\hline Age $>58$ & 0.037 & 0.188 & 0.034 & 0.181 & 0.207 & 0.406 & 0.037 & 0.188 & 0.028 & 0.165 & 0.012 & 0.107 & 0.132 & 0.339 & 0.022 & 0.146 \\
\hline Single & 0.466 & 0.499 & 0.471 & 0.499 & 0.532 & 0.499 & 0.297 & 0.457 & 0.543 & 0.499 & 0.531 & 0.499 & 0.456 & 0.498 & 0.421 & 0.494 \\
\hline Working partner & 0.374 & 0.484 & 0.361 & 0.480 & 0.257 & 0.437 & 0.418 & 0.493 & 0.475 & 0.500 & 0.521 & 0.500 & 0.514 & 0.500 & 0.565 & 0.496 \\
\hline Children $<16$ in the hh & 0.395 & 0.489 & 0.386 & 0.487 & 0.224 & 0.417 & 0.433 & 0.496 & 0.303 & 0.460 & 0.311 & 0.463 & 0.266 & 0.442 & 0.314 & 0.464 \\
\hline Own house & 0.412 & 0.493 & 0.424 & 0.494 & 0.516 & 0.500 & 0.537 & 0.499 & 0.357 & 0.480 & 0.396 & 0.489 & 0.408 & 0.492 & 0.476 & 0.499 \\
\hline Disabled & 0.082 & 0.274 & 0.053 & 0.225 & 0.106 & 0.308 & 0.039 & 0.194 & 0.088 & 0.283 & 0.054 & 0.227 & 0.094 & 0.292 & 0.045 & 0.206 \\
\hline \multicolumn{17}{|c|}{ Required training for the job } \\
\hline None/introductory & 0.143 & 0.350 & 0.114 & 0.318 & 0.094 & 0.292 & 0.083 & 0.277 & 0.232 & 0.422 & 0.163 & 0.369 & 0.152 & 0.360 & 0.175 & 0.380 \\
\hline On the job training & 0.201 & 0.401 & 0.152 & 0.359 & 0.139 & 0.346 & 0.185 & 0.388 & 0.134 & 0.341 & 0.146 & 0.353 & 0.126 & 0.332 & 0.158 & 0.365 \\
\hline Have taken courses & 0.517 & 0.500 & 0.489 & 0.500 & 0.447 & 0.497 & 0.541 & 0.498 & 0.505 & 0.500 & 0.517 & 0.500 & 0.466 & 0.499 & 0.541 & 0.498 \\
\hline Vocational training & 0.056 & 0.231 & 0.136 & 0.343 & 0.106 & 0.308 & 0.147 & 0.354 & 0.032 & 0.176 & 0.060 & 0.238 & 0.113 & 0.316 & 0.079 & 0.269 \\
\hline College & 0.083 & 0.277 & 0.109 & 0.311 & 0.214 & 0.410 & 0.044 & 0.204 & 0.098 & 0.297 & 0.114 & 0.318 & 0.143 & 0.350 & 0.047 & 0.212 \\
\hline \multicolumn{17}{|l|}{ Occupation } \\
\hline Unskilled & 0.095 & 0.293 & 0.074 & 0.262 & 0.060 & 0.237 & 0.046 & 0.210 & 0.325 & 0.469 & 0.270 & 0.444 & 0.239 & 0.427 & 0.256 & 0.436 \\
\hline Semi-skilled & 0.188 & 0.391 & 0.121 & 0.326 & 0.092 & 0.290 & 0.107 & 0.310 & 0.136 & 0.343 & 0.096 & 0.295 & 0.093 & 0.291 & 0.106 & 0.308 \\
\hline Skilled & 0.315 & 0.465 & 0.232 & 0.423 & 0.208 & 0.406 & 0.229 & 0.420 & 0.056 & 0.230 & 0.053 & 0.225 & 0.033 & 0.180 & 0.036 & 0.185 \\
\hline Professional, managerial & 0.336 & 0.473 & 0.437 & 0.496 & 0.310 & 0.463 & 0.438 & 0.496 & 0.421 & 0.494 & 0.487 & 0.500 & 0.424 & 0.494 & 0.492 & 0.500 \\
\hline Missing occupation & 0.066 & 0.249 & 0.135 & 0.342 & 0.329 & 0.470 & 0.180 & 0.384 & 0.062 & 0.241 & 0.093 & 0.291 & 0.211 & 0.408 & 0.110 & 0.313 \\
\hline \multicolumn{17}{|l|}{ Firm size } \\
\hline Firm size $<20$ & 0.387 & 0.487 & 0.232 & 0.423 & 0.178 & 0.383 & 0.141 & 0.348 & 0.441 & 0.497 & 0.333 & 0.471 & 0.255 & 0.436 & 0.240 & 0.427 \\
\hline Firm size $<200$ & 0.308 & 0.462 & 0.273 & 0.445 & 0.249 & 0.433 & 0.254 & 0.435 & 0.281 & 0.450 & 0.263 & 0.440 & 0.256 & 0.436 & 0.277 & 0.447 \\
\hline Firm size $<2000$ & 0.277 & 0.448 & 0.470 & 0.499 & 0.530 & 0.499 & 0.588 & 0.492 & 0.236 & 0.425 & 0.363 & 0.481 & 0.460 & 0.499 & 0.455 & 0.498 \\
\hline
\end{tabular}


Firm size $>2000$

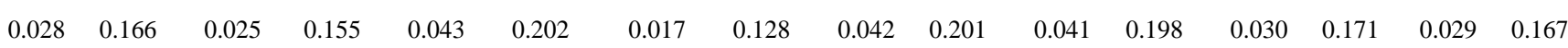

Industry of employment, tenure \& gross wage

Manufacturing

Wholesale trade, hotel \&res

Mining \& construction

Transport, finance, real estate

Social services

Missing industry

Full-time employed

Tenure

Tenure sq./100

Real gross hourly wage (ln)

Region

Berlin, Brandenberg, Saxony-anh, Trundia, Saxony Schleswig-H., Hamburg, Lower Saxony, Bremen,

Schleswig
Mecklen.

North Rhine-West., Hesse, Rhinel.-palatinate, saarl.

Baden-wuerttemberg, Bavaria

Time/year

1994-1985

1986-1987

1988-1989

1990-1993

1994-1996

$\begin{array}{llllll}0.359 & 0.480 & 0.355 & 0.479 & 0.331 & 0.471\end{array}$

$0.150 \quad 0.357$

$0.242 \quad 0.428$

$\begin{array}{ll}0.141 & 0.349\end{array}$

$\begin{array}{ll}0.055 & 0.228 \\ 0.054 & 0.226\end{array}$

$\begin{array}{ll}0.054 & 0.226 \\ 0.983 & 0.129\end{array}$

$\begin{array}{llllllll}6.813 & 8.901 & 6.330 & 7.906 & 11.551 & 13.281\end{array}$

$\begin{array}{lllllll}1.255 & 2.830 & 1.025 & 2.478 & 3.097 & 5.097\end{array}$

$\begin{array}{llllll}2.970 & 0.489 & 3.006 & 0.512 & 2.860 & 0.688\end{array}$

$\begin{array}{llllll}0.041 & 0.198 & 0.033 & 0.178 & 0.043 & 0.204\end{array}$

$\begin{array}{llllll}0.223 & 0.417 & 0.190 & 0.392 & 0.204 & 0.403\end{array}$

$\begin{array}{lllllll}0.417 & 0.493 & 0.407 & 0.491 & 0.447 & 0.497\end{array}$

$\begin{array}{llllll}0.319 & 0.466 & 0.371 & 0.483 & 0.306 & 0.461\end{array}$

$\begin{array}{llll}0.386 & 0.487 & 0.242 & 0.428\end{array}$

$\begin{array}{llllll}0.211 & 0.408 & 0.197 & 0.398 & 0.215 & 0.411\end{array}$

1997-1999

$\begin{array}{llllll}0.127 & 0.333 & 0.160 & 0.366 & 0.069 & 0.253\end{array}$

$\begin{array}{llll}0.097 & 0.295 & 0.309 & 0.463\end{array}$

$\begin{array}{llll}0.104 & 0.306 & 0.038 & 0.191\end{array}$

$\begin{array}{lllllll}0.231 & 0.422 & 0.150 & 0.357 & 0.174 & 0.379\end{array}$

$\begin{array}{llllll}0.016 & 0.125 & 0.018 & 0.132 & 0.019 & 0.138\end{array}$

$\begin{array}{llllll}0.181 & 0.385 & 0.151 & 0.358 & 0.153 & 0.360\end{array}$

$\begin{array}{llll}0.229 & 0.420 & 0.164 & 0.370\end{array}$

$\begin{array}{llll}0.151 & 0.358 & 0.153 & 0.360 \\ 0.441 & 0.497 & 0.388 & 0.487\end{array}$

$\begin{array}{llll}0.041 & 0.198 & 0.082 & 0.274\end{array}$

$\begin{array}{llll}0.974 & 0.158 & 0.663 & 0.473\end{array}$

$\begin{array}{llllll}0.068 & 0.252 & 0.043 & 0.203 & 0.051 & 0.219\end{array}$

$\begin{array}{lllllllllll}12.927 & 10.082 & 5.007 & 6.420 & 4.532 & 5.349 & 7.201 & 8.290 & 9.325 & 8.101\end{array}$

$\begin{array}{lllllllllll}2.687 & 3.518 & 0.662 & 1.630 & 0.491 & 1.279 & 1.205 & 2.536 & 1.526 & 2.406\end{array}$

$\begin{array}{llllllllll}3.180 & 0.456 & 2.717 & 0.483 & 2.764 & 0.516 & 2.828 & 0.557 & 2.911 & 0.477\end{array}$

2000-2002

$\begin{array}{llllll}0.086 & 0.281 & 0.186 & 0.389 & 0.089 & 0.284\end{array}$

$\begin{array}{llllllllll}0.032 & 0.177 & 0.062 & 0.241 & 0.034 & 0.180 & 0.040 & 0.195 & 0.042 & 0.202\end{array}$

$\begin{array}{llllll}0.051 & 0.220 & 0.192 & 0.394 & 0.093 & 0.291\end{array}$

$\begin{array}{llllll}0.232 & 0.422 & 0.174 & 0.379 & 0.271 & 0.445\end{array}$

$\begin{array}{llllll}0.205 & 0.404 & 0.107 & 0.309 & 0.189 & 0.392\end{array}$

$\begin{array}{llll}0.179 & 0.383 & 0.196 & 0.397\end{array}$

$\begin{array}{llll}0.444 & 0.497 & 0.405 & 0.491\end{array}$

$\begin{array}{llllll}0.185 & 0.388 & 0.169 & 0.375 & 0.183 & 0.387\end{array}$

$\begin{array}{llllll}0.144 & 0.351 & 0.102 & 0.303 & 0.150 & 0.357\end{array}$

$\begin{array}{llllllllll}0.126 & 0.332 & 0.090 & 0.286 & 0.128 & 0.334 & 0.033 & 0.180 & 0.111 & 0.314\end{array}$

$\begin{array}{lllllllllll}0.123 & 0.328 & 0.092 & 0.289 & 0.168 & 0.374 & 0.036 & 0.187 & 0.109 & 0.311\end{array}$

$\begin{array}{llllllllll}0.119 & 0.323 & 0.076 & 0.265 & 0.184 & 0.388 & 0.041 & 0.199 & 0.104 & 0.305\end{array}$

$\begin{array}{lllllllllll}0.223 & 0.416 & 0.248 & 0.432 & 0.195 & 0.396 & 0.312 & 0.463 & 0.216 & 0.412\end{array}$

$\begin{array}{lllllllllllll}0.357 & 0.135 & 0.342 & 0.134 & 0.341 & 0.106 & 0.307 & 0.202 & 0.401 & 0.153 & 0.360\end{array}$

No. of obs 708 2099 1105

26184 501 1819 1135 17036 
Table A4: Guest-workers

\begin{tabular}{|c|c|c|c|c|c|c|c|c|c|c|c|c|c|c|c|c|}
\hline & \multicolumn{8}{|c|}{ Men } & \multicolumn{8}{|c|}{ Women } \\
\hline & \multicolumn{2}{|c|}{ Layoff } & \multicolumn{2}{|c|}{ Quit } & \multicolumn{2}{|c|}{ Other } & \multicolumn{2}{|c|}{ Stayer } & \multicolumn{2}{|c|}{ Layoff } & \multicolumn{2}{|c|}{ Quit } & \multicolumn{2}{|c|}{ Other } & \multicolumn{2}{|c|}{ Stayer } \\
\hline & Mean & $\begin{array}{l}\text { Std. } \\
\text { dev }\end{array}$ & Mean & $\begin{array}{l}\text { Std. } \\
\text { dev }\end{array}$ & Mean & $\begin{array}{l}\text { Std. } \\
\text { dev }\end{array}$ & Mean & $\begin{array}{l}\text { Std. } \\
\text { dev }\end{array}$ & Mean & $\begin{array}{l}\text { Std. } \\
\text { dev }\end{array}$ & Mean & $\begin{array}{l}\text { Std. } \\
\text { dev }\end{array}$ & Mean & $\begin{array}{l}\text { Std. } \\
\text { dev }\end{array}$ & Mean & $\begin{array}{l}\text { Std. } \\
\text { dev }\end{array}$ \\
\hline \multicolumn{17}{|c|}{ Demographic characteristics } \\
\hline Age $<25$ & 0.297 & 0.457 & 0.348 & 0.477 & 0.352 & 0.479 & 0.124 & 0.330 & 0.223 & 0.417 & 0.329 & 0.470 & 0.361 & 0.481 & 0.136 & 0.343 \\
\hline Age25-34 & 0.284 & 0.452 & 0.371 & 0.483 & 0.164 & 0.371 & 0.254 & 0.435 & 0.212 & 0.410 & 0.368 & 0.483 & 0.374 & 0.485 & 0.241 & 0.428 \\
\hline Age35-44 & 0.157 & 0.365 & 0.148 & 0.355 & 0.077 & 0.267 & 0.244 & 0.430 & 0.230 & 0.422 & 0.183 & 0.387 & 0.056 & 0.231 & 0.289 & 0.453 \\
\hline Age45-54 & 0.174 & 0.379 & 0.089 & 0.286 & 0.114 & 0.318 & 0.274 & 0.446 & 0.259 & 0.439 & 0.090 & 0.287 & 0.070 & 0.255 & 0.256 & 0.436 \\
\hline Age $>=55$ & 0.088 & 0.283 & 0.044 & 0.205 & 0.292 & 0.455 & 0.104 & 0.305 & 0.076 & 0.265 & 0.030 & 0.171 & 0.139 & 0.347 & 0.078 & 0.268 \\
\hline Age $>58$ & 0.033 & 0.178 & 0.013 & 0.112 & 0.178 & 0.383 & 0.033 & 0.179 & 0.018 & 0.133 & 0.009 & 0.096 & 0.116 & 0.321 & 0.018 & 0.133 \\
\hline Single & 0.380 & 0.486 & 0.462 & 0.499 & 0.440 & 0.497 & 0.236 & 0.425 & 0.335 & 0.473 & 0.426 & 0.495 & 0.424 & 0.495 & 0.303 & 0.459 \\
\hline Working partner & 0.278 & 0.449 & 0.270 & 0.444 & 0.228 & 0.420 & 0.374 & 0.484 & 0.586 & 0.493 & 0.542 & 0.499 & 0.444 & 0.498 & 0.605 & 0.489 \\
\hline Children $<16$ in the hh & 0.554 & 0.498 & 0.526 & 0.500 & 0.430 & 0.496 & 0.586 & 0.493 & 0.493 & 0.501 & 0.484 & 0.500 & 0.387 & 0.488 & 0.458 & 0.498 \\
\hline Own house & 0.070 & 0.255 & 0.125 & 0.331 & 0.124 & 0.330 & 0.132 & 0.339 & 0.122 & 0.328 & 0.123 & 0.328 & 0.166 & 0.372 & 0.144 & 0.352 \\
\hline Disabled & 0.106 & 0.309 & 0.043 & 0.202 & 0.121 & 0.326 & 0.061 & 0.239 & 0.119 & 0.324 & 0.102 & 0.303 & 0.126 & 0.332 & 0.067 & 0.249 \\
\hline \multicolumn{17}{|c|}{ Required training for the job } \\
\hline None/introductory & 0.399 & 0.490 & 0.315 & 0.465 & 0.329 & 0.471 & 0.379 & 0.485 & 0.561 & 0.497 & 0.491 & 0.500 & 0.444 & 0.498 & 0.581 & 0.494 \\
\hline On the job training & 0.190 & 0.393 & 0.209 & 0.407 & 0.201 & 0.402 & 0.281 & 0.450 & 0.119 & 0.324 & 0.104 & 0.306 & 0.139 & 0.347 & 0.161 & 0.367 \\
\hline Have taken courses & 0.294 & 0.456 & 0.313 & 0.464 & 0.248 & 0.433 & 0.279 & 0.449 & 0.194 & 0.396 & 0.236 & 0.425 & 0.262 & 0.440 & 0.198 & 0.398 \\
\hline Vocational training & 0.016 & 0.127 & 0.023 & 0.149 & 0.017 & 0.129 & 0.018 & 0.131 & 0.004 & 0.060 & 0.016 & 0.126 & 0.023 & 0.151 & 0.016 & 0.126 \\
\hline College & 0.100 & 0.301 & 0.141 & 0.348 & 0.205 & 0.404 & 0.043 & 0.203 & 0.122 & 0.328 & 0.153 & 0.360 & 0.132 & 0.340 & 0.045 & 0.207 \\
\hline \multicolumn{17}{|l|}{ Occupation } \\
\hline Unskilled & 0.204 & 0.404 & 0.178 & 0.382 & 0.148 & 0.355 & 0.153 & 0.360 & 0.414 & 0.493 & 0.419 & 0.494 & 0.364 & 0.482 & 0.364 & 0.481 \\
\hline Semi-skilled & 0.393 & 0.489 & 0.314 & 0.464 & 0.393 & 0.489 & 0.424 & 0.494 & 0.396 & 0.490 & 0.294 & 0.456 & 0.295 & 0.457 & 0.408 & 0.492 \\
\hline Skilled & 0.282 & 0.451 & 0.298 & 0.458 & 0.178 & 0.383 & 0.282 & 0.450 & 0.032 & 0.177 & 0.035 & 0.183 & 0.030 & 0.170 & 0.039 & 0.195 \\
\hline Professional, managerial & 0.072 & 0.258 & 0.118 & 0.323 & 0.081 & 0.273 & 0.103 & 0.304 & 0.104 & 0.306 & 0.185 & 0.389 & 0.166 & 0.372 & 0.151 & 0.358 \\
\hline Missing occupation & 0.049 & 0.216 & 0.092 & 0.290 & 0.201 & 0.402 & 0.039 & 0.193 & 0.054 & 0.226 & 0.067 & 0.251 & 0.146 & 0.353 & 0.038 & 0.190 \\
\hline \multicolumn{17}{|l|}{ Firm size } \\
\hline Firm size $<20$ & 0.276 & 0.448 & 0.307 & 0.462 & 0.221 & 0.416 & 0.137 & 0.344 & 0.295 & 0.457 & 0.313 & 0.464 & 0.301 & 0.460 & 0.197 & 0.398 \\
\hline Firm size $<200$ & 0.333 & 0.472 & 0.311 & 0.463 & 0.242 & 0.429 & 0.265 & 0.441 & 0.327 & 0.470 & 0.262 & 0.440 & 0.232 & 0.423 & 0.257 & 0.437 \\
\hline Firm size $<2000$ & 0.352 & 0.478 & 0.339 & 0.474 & 0.493 & 0.501 & 0.569 & 0.495 & 0.320 & 0.467 & 0.361 & 0.481 & 0.440 & 0.497 & 0.508 & 0.500 \\
\hline Firm size $>2000$ & 0.039 & 0.193 & 0.043 & 0.202 & 0.044 & 0.205 & 0.030 & 0.170 & 0.058 & 0.233 & 0.065 & 0.246 & 0.026 & 0.161 & 0.038 & 0.192 \\
\hline
\end{tabular}


Industry of employment, tenure \& gross wage

\begin{tabular}{|c|c|c|c|c|c|c|c|c|c|c|c|c|c|c|c|c|}
\hline Manufacturing & 0.470 & 0.500 & 0.446 & 0.497 & 0.513 & 0.501 & 0.599 & 0.490 & 0.453 & 0.499 & 0.319 & 0.467 & 0.354 & 0.479 & 0.465 & 0.499 \\
\hline Wholesale trade, hotel \&res & 0.131 & 0.338 & 0.172 & 0.378 & 0.097 & 0.297 & 0.072 & 0.258 & 0.234 & 0.424 & 0.231 & 0.422 & 0.166 & 0.372 & 0.135 & 0.342 \\
\hline Mining \& construction & 0.229 & 0.421 & 0.148 & 0.355 & 0.168 & 0.374 & 0.151 & 0.358 & 0.011 & 0.104 & 0.007 & 0.083 & 0.003 & 0.058 & 0.003 & 0.057 \\
\hline Transport, finance, real estate & 0.072 & 0.258 & 0.118 & 0.323 & 0.074 & 0.262 & 0.073 & 0.260 & 0.094 & 0.292 & 0.125 & 0.331 & 0.109 & 0.312 & 0.102 & 0.303 \\
\hline Social services & 0.027 & 0.161 & 0.043 & 0.202 & 0.060 & 0.239 & 0.040 & 0.195 & 0.104 & 0.306 & 0.199 & 0.400 & 0.315 & 0.465 & 0.210 & 0.407 \\
\hline Missing industry & 0.072 & 0.258 & 0.074 & 0.262 & 0.087 & 0.283 & 0.067 & 0.249 & 0.104 & 0.306 & 0.118 & 0.323 & 0.053 & 0.224 & 0.084 & 0.278 \\
\hline Full-time employed & 0.986 & 0.119 & 0.972 & 0.166 & 0.966 & 0.180 & 0.982 & 0.134 & 0.770 & 0.422 & 0.727 & 0.446 & 0.834 & 0.372 & 0.795 & 0.404 \\
\hline Tenure & 6.217 & 7.592 & 4.782 & 6.012 & 8.871 & 10.394 & 10.942 & 8.069 & 5.329 & 6.511 & 4.817 & 5.541 & 6.251 & 7.923 & 9.036 & 7.362 \\
\hline Tenure sq./100 & 0.962 & 2.026 & 0.590 & 1.346 & 1.864 & 3.101 & 1.848 & 2.288 & 0.706 & 1.560 & 0.538 & 1.346 & 1.016 & 2.333 & 1.358 & 1.958 \\
\hline Real gross hourly wage (ln) & 2.876 & 0.434 & 2.811 & 0.506 & 2.790 & 0.585 & 3.027 & 0.403 & 2.654 & 0.423 & 2.637 & 0.443 & 2.678 & 0.530 & 2.782 & 0.405 \\
\hline \multicolumn{17}{|l|}{ Region } \\
\hline Berlin, Brandenberg, Saxony-anh, Trundia, Saxony & 0.065 & 0.248 & 0.031 & 0.174 & 0.040 & 0.197 & 0.019 & 0.137 & 0.058 & 0.233 & 0.049 & 0.215 & 0.023 & 0.151 & 0.025 & 0.155 \\
\hline Schleswig-H., Hamburg, Lower Saxony, Bremen, Mecklen. & 0.078 & 0.268 & 0.115 & 0.319 & 0.107 & 0.310 & 0.088 & 0.283 & 0.079 & 0.270 & 0.097 & 0.297 & 0.093 & 0.291 & 0.090 & 0.286 \\
\hline North Rhine-West., Hesse, Rhinel.-palatinate, saarl. & 0.419 & 0.494 & 0.418 & 0.494 & 0.423 & 0.495 & 0.449 & 0.497 & 0.381 & 0.487 & 0.419 & 0.494 & 0.417 & 0.494 & 0.406 & 0.491 \\
\hline Baden-wuerttemberg, Bavaria & 0.438 & 0.497 & 0.436 & 0.496 & 0.430 & 0.496 & 0.444 & 0.497 & 0.482 & 0.501 & 0.433 & 0.496 & 0.467 & 0.500 & 0.479 & 0.500 \\
\hline \multicolumn{17}{|l|}{ Time/year } \\
\hline 1994-1985 & 0.121 & 0.326 & 0.132 & 0.339 & 0.027 & 0.162 & 0.142 & 0.349 & 0.112 & 0.315 & 0.102 & 0.303 & 0.017 & 0.128 & 0.122 & 0.327 \\
\hline 1986-1987 & 0.131 & 0.338 & 0.195 & 0.396 & 0.081 & 0.273 & 0.132 & 0.338 & 0.090 & 0.287 & 0.162 & 0.369 & 0.017 & 0.128 & 0.118 & 0.323 \\
\hline 1988-1989 & 0.078 & 0.268 & 0.168 & 0.374 & 0.047 & 0.212 & 0.134 & 0.340 & 0.086 & 0.281 & 0.194 & 0.396 & 0.030 & 0.170 & 0.123 & 0.328 \\
\hline 1990-1993 & 0.260 & 0.439 & 0.193 & 0.395 & 0.329 & 0.471 & 0.242 & 0.428 & 0.309 & 0.463 & 0.204 & 0.403 & 0.328 & 0.470 & 0.249 & 0.433 \\
\hline 1994-1996 & 0.182 & 0.386 & 0.112 & 0.316 & 0.211 & 0.409 & 0.142 & 0.349 & 0.158 & 0.366 & 0.118 & 0.323 & 0.248 & 0.433 & 0.152 & 0.359 \\
\hline 1997-1999 & 0.112 & 0.316 & 0.111 & 0.314 & 0.185 & 0.389 & 0.112 & 0.316 & 0.112 & 0.315 & 0.116 & 0.320 & 0.212 & 0.409 & 0.119 & 0.324 \\
\hline $2000-2002$ & 0.117 & 0.321 & 0.089 & 0.286 & 0.121 & 0.326 & 0.097 & 0.296 & 0.133 & 0.340 & 0.104 & 0.306 & 0.149 & 0.357 & 0.117 & 0.322 \\
\hline No. of obs & 489 & & 704 & & 298 & & 10676 & & 278 & & 432 & & 302 & & 5851 & \\
\hline
\end{tabular}




\section{References}

Anderson MP and Meyer BD (1994) The Extent and Consequences of Job Turnover. Brookings Papers on Economic Activity: Microeconomics: 177-248

Becker GS (1962) Investment in Human Capital: A Theoretical Analysis. Journal of Political Economy 70(2): S9-S49.

Becker GS (1964) Human Capital: A Theoretical and Empirical Analysis, with Special Reference to Education. New York: National Bureau of Economic Research, Columbia University Press.

Ben-Porath Y (1976) The Production of Human Capital and the Life Cycle of Earnings. Journal of Political Economy 75: 352 - 365.

Bergemann A \& Mertens A (2004) Job Stability Trends, Layoffs, and Transitions to Unemployment: An Empirical Analysis for West Germany, IZA Discussion Paper No. 1368.

Blau and Kahn (1981) Causes and Consequences of Layoffs. Economic Inquiry Vol. 19: 270-296

Burda M and Mertens A (2001) Estimating wage losses of separated workers in Germany. Labour Economics 8: 15 - 41

Burdettt K (1978) The Theory of Employee Job Search and Quit Rates. The American Economic Review 68(1): 212-220.

Cramer J and Ridder G (1991) Pooling States in the Multinomial Logit Model. Journal of Econometrics 47(2-3):267-272.

Devine T and Kiefer N (1991) Empirical Labour Economics: The Search Approach. Oxford University Press.

Fallick CB (1996) A Review of the Recent Empirical Literature on Displaced Workers. Industrial and Labour Relation Review 50(1): 5-16.

Farber H (1993) The Incidence and Costs of Job Loss, 1982-91. Brookings Papers: Microeconomics: 73-132.

Farber H (1997) The Changing Face of Job Losses in the United States, 1981-1995. Brookings Papers: Microeconomics: 55-142.

Hall RE (1972) Turnover in the Labour Market. Brookings Papers on Economic Activity, 3: 709-765.

Hamermesh D (1989) What Do We Know About Worker Displacement in the U.S.? Industrial Relations 28(1): 51-59.

Hausman JJ and McFadden D (1984) Specification Tests for the Multinomial Logit Model. Econometrica, 52(5): 1219-1240

Heckman J (2002) Flexibility and Job Creation: Lessons from Germany. NBER Working Paper Series, WP 9194, National Bureau of Economic Research.

Heckman J and Singer B (1984) The Identifiability of the Proportional Hazards Model. Review of Economic Studies 51: 231 - 241.

Jovanovic B (1979a) Job Matching and the Theory of Turnover. The Journal of Political Economy 87(5): 972-990.

Jovanovic B (1979b) Firm-Specific Capital and Turnover. The Journal of Political Economy 87(6): 1246-1260.

Jovanovic B (1984) Matching, Turnover, and Unemployment. The Journal of Political Economy 92(1): 108-122.

Kletzer L (1998) Job Displacement. Journal of Economic Perspectives: 12(1)

McCall J (1970) Economics of Information and Job Search. Quarterly Journal of Economics 84: 113 - 126. 
McLaughlin K (1991) A Theory of Quits and Layoffs with Efficient Turnover. Journal of Political Economy 99(1):75-98.

Mincer J (1958) Investment in Human Capital and Personal Income Distribution. Journal of Political Economy 66(4): 281-302.

Mincer J (1962) On-the-Job Training: Costs, Returns, and Some Implications. Journal of Political Economy 70(5-2): S50 - S79.

Mortensen D (1977) Unemployment Insurance and Job Search Decisions. Industrial and Labour Relations Review 30: 505 - 517.

Mortensen D (1986) Job Search and Labour Market Analysis. In: Ashenfelter and Layard (eds.) Handbook of Labour Economics 2 Elsevier Science Publishers, Amsterdam: North Holland: 849-920.

Mortensen D and Pissarides C (1999) New Developments in Models of Search in the Labour Market. In: Ashenfelter and Card (eds.) Handbook of Labour Economics 3 Elsevier Science Publishers, Amsterdam: North Holland: 25672627.

Parsons DO (1972) Specific Human Capital: An Application to Quit Rates and Layoff Rates. Journal of Political Economy 80: 1120 - 1143.

Salop J and Salop S (1976) Self-Selection and Turnover in the Labour Market. Quarterly Journal of Economics 90 (4): 619 - 627.

Schultz TW (1960) Capital Formation by Education. Journal of Political Economy 68(8): $571-583$.

Schultz TW (1961) Investment in Human Capital. American Economic Review 51(1): 117.

Spence M (1973) Job Market Signalling. Quarterly Journal of Economics 87(3): 355374.

Weiss A (1995) Human Capital Vs. Signalling Explanations of Wages. Journal of Economic Perspective 9(4): 133-154.

Wills R (1986) Wage Determinants: A Survey and Interpretation of Human Capital Earnings Functions. In: Ashenfelter O and Layard R (eds.) Handbook of Labour Economics. 1 Elsevier Science Publishers, Amsterdam: North Holland: 525 602

Winkelmann R and Zimermann K (1998) Is job stability declining in Germany? Evidence from count data models. Applied Economics 30:1413-1420. 


\section{Endnotes}

${ }^{1}$ Detailed accounts of the SOEP can be obtained from http://www.diw.de/soep. Over the years the Soep has been extended to include different sub-samples of the German households. For example, the survey was extended in 1991 to include representative households from the former East Germany. ${ }^{2}$ There is the legitimate question of some workers experiencing more than one job change over the period in question. Nevertheless, it is not an unrealistic assumption that such cases are too few to change our findings, particularly considering the case that most of our sample members make up the full-time employment category.

${ }^{3}$ An hourly real gross wage has then been computed from the hours and earnings information having first converted the earnings into real using CPI data obtained from

http://www.destatis.de/indicators/e/vpi001ae.htm

${ }^{4}$ Disability is defined as being out of work for more than 6 weeks.

${ }^{5}$ The plots that appear in the figures are for movers only while the balance in each case represent the proportion of 'stayers' in each year covered by the study.

${ }^{6}$ As indicated in note 2 to Table A1 in the appendix, there are more reasons making up 'quits' and 'other' separations during the 1985-1990 period. However, most of the additional reasons monitored during this period are not main reasons for separation but monitored as additional/contributing factors. As such, the assumption that these reasons are subsumed under the other reasons monitored in other years is justified.

${ }^{7}$ Turnover theories have long established that 'quits' are pro-cyclical while 'layoffs' are counter cyclical. Figures A5 and A6 do not exhibit this pattern as 'clearly' which may have to do with the level of the shock (re-unification) that distorted such patterns. Also, women are more likely to quit than their male counterparts due mainly to family and domestic responsibilities.

${ }^{8}$ The 'Cramer and Ridder (1991) test statistic is give by $L R=2\left\{\log L_{U}-\log L_{R}\right\}$, where $\log L_{U}$ is

the maximum log-likelihood of the full model while $\log L_{R}$ is the maximum log-likelihood of the restricted model, and has an asymptotic chi-squared distribution with $k$ degrees of freedom where $k$ is the number of restrictions. $\log L_{U}$ is obtained from the full model while the log-likelihood of the restricted model is obtained as: $\log L_{R}=\sum_{j} n_{s j} \log n_{s j}-n_{s} \log s_{s}+\log L_{A}$, where $\log L_{A}$ is the unconstrained maximum log-likelihood of the pooled model,$s$ refers to the pooled state, $j$ refers to the separate states within $s, n_{\mathrm{s}}$ is the number of sample observations in the pooled state $s, \mathrm{n}_{\mathrm{sj}}$ is the number of the sample observations in each of the separate states $j$, and the sum of the number of observations in all separate states equals the number of observations in the pooled state, i.e. $\sum_{j} n_{s j}=n_{s}$. This test is particularly essential given the need to establish that the category 'Other' separation is indeed different from the 'Layoff' and 'Quit' categories.

${ }^{9}$ As well as the tests for the pooling of alternative categories, the other traditional test of importance related to the MNL models has to do with testing the validity of the IIA property (Hausman and McFadden 1984). In this study IIA tests have been conducted and the nulls that 'odds of any two outcomes are independent of other alternatives' have not been rejected.

${ }^{10}$ The additional parameters characterising the unobserved heterogeneity term should satisfy the

condition that $\stackrel{M}{\Sigma} \pi_{m}=1, \pi_{m} \geq 0$ and $\stackrel{M}{\sum} \pi_{m} \theta_{m}=0$. The estimation of the mixed multinomial logit $m=1 \quad m=1$

model (MMNL) is conducted using GLLAMM (http://www.gllamm.org).

${ }^{11}$ These estimates are not marginal effects. Marginal effects of the explanatory variables are dependent on the mixture (random effects) terms as well as terms relating to the explanatory variables in the models. As such, the computation of marginal effects is not straightforward.

${ }^{12}$ The 'Social services' industry is commonly eliminated from an analysis of the sort made in this study on the ground that it does not represent 'private' sector employment.

${ }^{13}$ The relationship between the log odds for class 1 and the estimated probability $\left(\hat{\pi}_{1}\right)$ associated with mass point 1 is give as $\hat{\pi}_{1}=\exp \left(p_{1}\right) /\left(1+\exp \left(p_{1}\right)\right.$. Mass point 2 and the associated probability are obtained using the conditions stated in footnote 9 above. 